\title{
Transmission of Monetary Policy Impulses on Bank Retail Interest Rates: An Empirical Study of Sri Lanka \\ Theja Dedu Samarasinghe Pathberiya
}

\begin{abstract}
The study examines the transmission of monetary policy impulses to bank retail interest rates in Sri Lanka. Understanding the interest rate pass-through process, from policy rates to bank retail rates are imperative to conduct monetary policy operations successfully. The variables used in this study are central bank policy interest rates that are repo and reverse repo rates, overnight interbank call money market rates, and various types of commercial bank lending and deposit rates. Among other econometric techniques, the Error Correction Mechanism is used in the present study as a main technique to analyse the interest rate pass through mechanism empirically. The data is for the 10-year period from 2003 to 2013. The key conclusion is, in general, that there is no one for one interest rate pass-through to the long-run commercial bank rates from money market rate. Nevertheless, there is a sizable and satisfactory pass-through in the long-run in fixed deposit rates. In contrast, the long-run pass-through is not satisfactory with regard to retail loan interest rates. In the short-run, bank retail rates deviated from the equilibrium due to monetary policy shocks, but were adjusted to their equilibrium levels in the long-run. Also it was found that, on average, short-run adjustment speed of deposit rates is less compared with the lending rates. Further, the short-run adjustment speed is higher for shorter maturities. In general, there is no asymmetry in interest rate pass-through in Sri Lanka.
\end{abstract}

Key Words: Monetary Policy, Interest Rate Pass-through, Central Bank of Sri Lanka, Asymmetry

JEL Classification: E52, E43, E58, D82 


\section{Introduction}

\subsection{Background}

Monetary policy Transmission Mechanism (MTM) can be broadly defined as the process through which central bank monetary policy actions are transmitted into changes in the real GDP and inflation [Taylor (1995)]. The MTM commences with monetary policy actions of central banks. Central banks have multiple tools at their disposal to initiate the transmission process with the objective of achieving policy targets. They range from occasionally used changes in interest on reserves to highly used open market operations (OMO) [Mishkin (2013)]. Modern central banks mostly choose between two policy operational targets to transfer their stance into the real economy: the policy interest rates and the monetary base.

The transmission of interest rate channel is broadly divided into two stages. The first stage is the interest rate pass-through from central bank tools to retail interest rates. The retail interest rates are the lending and deposit rates of commercial banks and other non-bank deposit taking institutions. The second stage is the transmission of the changes in retail interest rates to the aggregate demand and thereby the whole economy. The focus of this study is to understand the second part of stage one, i.e. the interest rate transmission from money market rates to various bank retail rates, in the case of Sri Lanka. The first part of stage one is the interest rate transmission from central bank policy rates to money market rates. Normally, it is accepted that there are lesser asymmetries in this stage. The analysis in this study focuses on the effect of monetary policy stances on the lending and deposit rates of commercial banks in Sri Lanka.

Sri Lanka is an emerging open market economy with an independent monetary authority, the Central Bank of Sri Lanka (CBSL). The CBSL monetary policy follows two key monetary policy objectives. The first objective is to achieve price and economic stability within the Sri Lankan economy. The second is to achieve financial system stability. Until recently, the CBSL dealt with the objective of price stability with a monetary targeting framework. The purpose of the monetary targeting framework was to influence the broad money supply in order to achieve the final target of price stability. 
1.2 Importance of Understanding Transmission of Monetary Impulses on Bank Retail Interest Rates

Understanding the interest rate pass-through process, from policy rates to bank retail rates is imperative to conduct monetary policy operations. Having a better understanding of monetary policy impulses on retail bank interest rates is important in two aspects. First, it is an important part in the whole transmission mechanism of monetary policy. Correct assessment of the impact of monetary policy changes on retail market rates is an essential step to understand and foresee the effects of monetary conditions on the real economy. Second, it is an important aspect of the soundness of the banking sector of a country. Aziakpono and Wilson (2010) demonstrate that the completeness in the long or short-run and to the asymmetry of the pass-through are ways of gauging the degree of competitiveness and the soundness of the financial system, especially the banking sector. Accordingly, it is clear that an effective transmission of monetary policy impulses to bank retail rates is important to have a smooth process of monetary policy and thereby to achieve both the

price stability and financial stability. A complete or nearly complete pass-through of interest rate is essential to achieve the ultimate goals of monetary policy. If policy makers have a better understanding of the degree and the speed of the pass-through, they can make better statements to the market regarding the expected effects of a particular change of monetary policy.

\subsection{Measuring Interest Rate Pass-through}

When analysing the interest rates pass-through process there are some important questions that should be raised, such as; What is the extent to which monetary policy impacts/influences retail bank rates? What is the time lag before retail bank rates are affected? Is there any asymmetric effect involved in the process of interest rate passthrough? Based on the literature on this topic, many scholars have attempted to answer these questions using many different approaches, both statistical and econometric tools. However, it is possible to categorize all of these tools under three main categories of simple regression analysis, vector auto regression analysis and the error correction analysis. There are many 
advantages as well as loopholes in each of these methods. Among these methods the error correction mechanism (ECM) is very popular in the study of interest rate pass-through. The ECM has the ability and the capacity to observe both the short-term adjustment of the bank retail interest rates to policy rates changes and the long-run pass-through of the policy rates to bank retail rates. The ECM also has the ability to explain how the variables adjust to deviations from long-run equilibrium. Additionally, ECM accounts for the integration of variables that are used in the analysis.

\subsection{Research Motivation}

Sri Lanka has implemented a monetary targeting framework since 1980s. Further, Sri Lanka is expected to move toward an inflation targeting framework in the coming years [CBSL Annual Report (2011)]. An important element of both these policy frameworks is to understand the whole monetary transmission mechanism. The first step of such transmission is the interest rate pass-through to various types of retail market interest rates. According to the literature reviewed, there is only a handful of studies conducted on interest rate passthrough in Sri Lanka. However, those few studies conducted on interest rate pass-through have not considered the bank retail rates comprehensively. It is essential to understand how monetary policy impulses affect across different maturities of deposit rates and various types of lending rates such as rates on secured and unsecured loan rates. The most recent study done in this regard is Amarasekara (2005).

Furthermore, the studies conducted on interest rate pass-through are out-dated as they used data prior to 2003, before competitive OMO were adopted. The CBSL moved into a system of active OMO in 2003 from a passive OMO approach so as to conduct its monetary policy operations more effectively and in a market based manner. This was against the former conduct of monetary policy of non market oriented monetary policy measures such as credit ceilings, quantitative controls and statutory reserve requirements, which operate through regulations. 
Additionally, the existing studies conducted do not have a comprehensive study of asymmetry of the interest rate pass-through due to monetary policy impulses. It would be beneficial to the CBSL to have knowledge of such impact through a comprehensive study.

\subsection{Objectives of the Study}

The broad objective of the present study is to contribute to the understanding of the interest rate pass-through process in Sri Lanka. More precisely, the analysis focuses on the passthrough between money market interest rates on overnight maturities and various kinds of deposit and lending rates of commercial banks. The deposit rates include savings rates and various other maturities spanning from 3 months to 24 months. The lending rates include various types of secured and non-secured loan interest rates. The study will look into the following aspects of the interest rate pass-through with regard to the above discussed retail bank rates, i) Speed of adjustment, ii) Completeness and iii) Asymmetric impact of monetary policy impulses. The study period covers a decade, from 2003 to 2013. The empirical analysis is done using econometrics tools such as Unit root test, Cointegration test, Error Correction Mechanism.

\section{Monetary Policy and Commercial Banking in Sri Lanka}

\subsection{Introduction}

Sri Lanka is a small open economy, which has experienced a series of political regime changes, and as a result, has adopted a wide range of economic regimes as well. However, the most influential economic regime began during the late 1970s with a pro-market economy regime gaining power in Sri Lanka. During the early years of this regime, the economic policies went through radical change, moving from a closed economy fixed (pegged) exchange rate policies (from 1970 - 1976) to semi-liberalised managed-floating exchange rate, known as 'crawling peg', with a sequence of actions to integrate Sri Lanka to the fast globalizing economy after 1977. Trade liberalization was another key policy initiative [Thenuwara (1998)]. 
Sri Lanka was not able to defend the crawling peg regime for long, as it was responsible for the depletion of foreign exchange reserves. Consequently, Sri Lanka was forced to abandon the policy in 2001 and to initiate a floating exchange rate regime with the monetary targeting framework. One of the key objectives of such monetary policy framework is price stability. The monetary targeting policy is being implemented presently by the monetary authority of Sri Lanka, the CBSL.

\subsection{Monetary Policy Framework}

\subsubsection{Monetary Policy Objectives}

Before the amendments to the Monetary Law Act in 2002, the CBSL's monetary policy objectives focused on economic stabilisation and enhancing economic development. After 2002, in line with the general global trend in conducting market oriented monetary policy, CBSL also began to place a greater reliance on OMO as its main instrument of monetary policy. As a major change in its policy thrust, in March 2003, the CBSL moved from a system called 'passive' OMO to a system of more 'active' OMO in order to improve the effectiveness of monetary policy operations.

\subsubsection{Monetary Targeting}

Under the monetary aggregate targeting monetary policy framework of the CBSL, the intermediate objective is to influence the broad money supply, more precisely M2 $\mathrm{b}^{1}$ through policy instruments. Money supply is linked to bank reserves that the CBSL calls 'reserve money' through the money multiplier. Accordingly, reserve money is the operating target while broad money supply is the intermediate target in the CBSL monetary framework. The reserve money target and the broad money targets are announced quarterly. The principal tools under the direct control of the central bank to achieve the path of the reserve money target are the volume of reserve money injected or withdrawn through the Open Market Operations (OMO), and the pair of official rates that forms the floor and the ceiling for eligible

${ }^{1} \mathrm{M} 2 \mathrm{~b}$ is defined as the sum of currency, demand deposits, savings and time deposits. 
commercial bank bidding rates in the auction organised for their 'overnight repo' or 'reverse repo' with the Central Bank [CBSL Annual Report (2014)]. These tools will be described in more details later.

The following Figure 2.1 summarizes the monetary policy targeting framework in Sri Lanka.

\section{Figure 2.1: Monetary Targeting Framework of Sri Lanka}

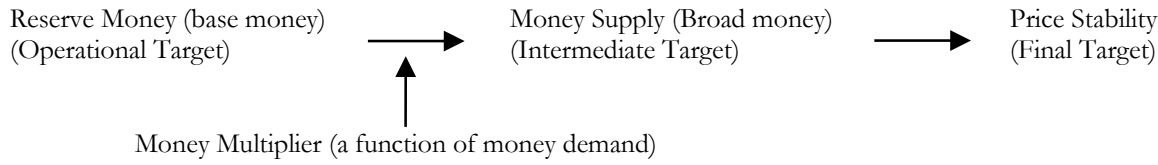

\subsubsection{Monetary Policy Tools}

There are several monetary policy tools such as OMO, official repo and reverse repo, central bank rates and statutory reserve requirement available to conduct monetary policy. However, at present OMO volume and official rates are actively utilized by the CBSL to achieve monetary policy goals. In line with the international trend of using more market oriented tools, the CBSL widely uses OMO as the primary policy tool, in addition to direct controls through non-market tools such as bank rates and credit controls. Amarasekara (2008) points out that the CBSL gradually moved away from the direct controls toward market-oriented mechanism during late 1970s with the liberalization of the domestic economy. Accordingly, the use of administratively determined bank rates and the use of credit controls were gradually abandoned.

OMO: The OMO are carried out mainly using government securities. The active OMO encourages competition in the money market and for participating institutions to improve their liquidity management. As explained above, the system operates within an explicit monetary targeting monetary policy framework. Monetary targeting has become more important with the floating of the rupee as the exchange rate no longer serves as a nominal anchor for monetary policy. In this framework, the final target of economic and price 
stability is to be achieved through an intermediate target on the broad money supply which, in turn, is linked to a time path of operating targets on the reserve money. OMO are conducted to ensure the achievement of reserve money targets while maintaining interbank overnight interest rates, on which the impact of monetary policy decisions is reflected almost instantaneously, stable within a narrow range. Key elements of the OMO system are fourfold, and are given as follows; a) An interest rate corridor, b) Daily auction of either repo or reverse repo to maintain the interbank rate stable within the corridor, c) Standing facilities and d) Outright buying/selling of Treasury bills/bonds at the discretion of the Central Bank to either inject or absorb long-term liquidity.

\subsection{Banking Activities in Sri Lanka}

The banking activities in Sri Lanka are governed by the CBSL using three main acts; the Monetary Law Act, the Banking Act and the Exchange Control Act. The banking sector in Sri Lanka comprises of licensed commercial banks (LCBs) and licensed specialised banks (LSBs). The CBSL issues banking licenses for these two categories of banks. The difference between LCBs and LSBs lies in the range of activities they can undertake. LSBs are licensed to conduct specialised banking that includes specialised savings banks and development banks. LCBs have a broader scope compared to LSBs. LCBs are permitted to accept demand deposits from the public (operate current accounts for customers) and they are authorized dealers in foreign exchange which entitles them to engage in a wide-range of foreign exchange transactions. However LSBs are permitted limited engagements in foreign exchange with CBSL's approvals. These two sectors dominate the financial system and accounts for more than 55 per cent of the total assets of the financial system in Sri Lanka (CBSL Annual report 2013). The total assets and deposit liabilities of the LCBs and LSBs are given in Table 2.1. 
Table 2.1: Total Assets and Deposit Liabilities of LCBs and LSBs

\begin{tabular}{|c|c|c|c|c|}
\hline \multirow{3}{*}{$\begin{array}{l}\text { Financial } \\
\text { Institution }\end{array}$} & \multicolumn{4}{|c|}{2013} \\
\hline & \multicolumn{2}{|c|}{ Assets } & \multicolumn{2}{|c|}{ Deposits } \\
\hline & Rs Bn & Share $(\%)$ & Rs Bn & Share $(\%)$ \\
\hline LCBs & $5,022.2$ & 48.7 & $3,552.4$ & 77.7 \\
\hline LSBs & 919.3 & 8.9 & 617.1 & 13.5 \\
\hline Total & $5,941.5$ & 57.6 & $4,169.5$ & 91.2 \\
\hline
\end{tabular}

Source: Financial Stability Review of CBSL 2013

Banking sector play a central role within the financial system, as they have the capacity to provide liquidity to the entire economy. Also, banks are responsible for providing payment services, thereby facilitating all entities to carry out their economic transactions. Table 2.2 gives the banking sector network in Sri Lanka.

Table 2.2 gives the composition of assets and liabilities of the banking sector.

Table 2.2: Composition of Assets and Liabilities of Banking Sector

\begin{tabular}{lc}
\hline \hline Year 2013 & \% of Total \\
\hline Assets & \\
\hline Loans & 57.7 \\
Investments & 28.5 \\
Other & 13.8 \\
\hline Liabilities & \\
\hline Deposits & 70.2 \\
Borrowings & 17.1 \\
Capital Funds & 8.2 \\
Other & 4.5 \\
\hline
\end{tabular}

Source: Financial Stability Review of CBSL-2013 


\subsubsection{Licensed Commercial Banks in Sri Lanka}

As LCBs are the most significant category of the Sri Lankan financial sector, they are subject to examination by the CBSL in terms of the provisions of the Banking and Monetary Law Acts. Accordingly, examinations are conducted by the Bank Supervision Department of CBSL.

In terms of the asset base and the extent of services provided, the LCBs are the most significant category of financial institutions within the banking sector. In this study, the passthrough of money market rates to lending and deposit rates of LCB sector is analysed. As at the end of 2013, the LCBs dominated the financial system with a market share of around 48 per cent of the entire financial system's assets and around 86 per cent of the banking sector's assets. Therefore, the financial system's stability of Sri Lanka mostly depends on the soundness of the LCBs.

As at end of 2013, the commercial banking sector comprised of 24 LCBs. Even though a large number of LCBs exist in the country, the stability of the financial system primarily depends on the performance and financial strength of the six largest LCBs, consisting of the two state banks and the four largest domestic private commercial banks. These six banks are referred to as the Systemically Important Banks (SIBs), representing around 77 per cent of the LCB sector assets and around 66 per cent of the whole banking sector assets.

\section{Interest Rate Pass-through Mechanism}

\subsection{Introduction}

The monetary policy decisions by central banks regarding the official interest rates affect economic activities and inflation through several channels (i.e. interest rate channel, asset price channels, exchange rate channel, credit channels) which are collectively known as the 'transmission mechanism' of monetary policy. In this section, special attention is given to a particular type of channel: the interest rate channel. 


\subsection{The Monetary Policy Transmission Mechanism}

Different degree and speed of pass-through and asymmetries are fundamental facts associated throughout the monetary policy transmission process. Therefore, it is difficult to predict the effect of monetary policy action on the economy. However, since then many economists have tried to understand the whole process of the monetary transmission mechanism in different ways. According to these analyses the monetary policy transmission mechanism can be decomposed into two stages.

Stage one is the change in the policy interest rate set by the central bank transmitted to the retail interest rates through various channels. For example, changes in the policy interest rate affect other retail interest rates such as loans and deposits rates offered by banks and other financial institutions through the changes in money market rates. This is called the interest rate channel of the monetary policy transmission. There are also several other channels that transfer the changes in policy interest rates to the economy. The monetary policy changes affect the prices of many assets such as shares, securities etc. and is referred to as asset price channel of the monetary policy transmission. Further, the monetary policy rate changes affect the foreign exchange rate of a country and this is called the exchange rate channel of the monetary policy transmission. Finally, it may also impact the expectations of economic agents such as firms, investors and individuals simultaneously, which describes the expectation channel of the monetary policy [(Ireland (2005)].

Stage two describes that these changes in retail interest rates will affect the consumption and investment spending patterns of the main economic agents, i.e. consumers and firms and thereby the whole economy. As an example, a higher interest rate will reduce the level of aggregate demand, as consumers and investors are affected by the increase in interest rates. This effect will reduce spending. There will also be an effect on aggregate demand due to imports and exports changing in response to changes in the exchange rate. The reduction in total demand will impact on overall economy as it reduces the production and thereby employment in the economy. 


\subsection{The Market Interest Rates}

Market interest rates can be classified according to the maturity of the investment: they are either short-term interest rates or long-term interest rates. A change in the policy rate is immediately transmitted to other short-term money-market interest rates such as overnight interbank repo rates. However, these rates may not always move by the exact amount as the official rate change. Soon after the policy rate change, banks adjust their standard lending and deposit rates for short term maturities. This immediately affects the interest rates that banks charge their institutional customers on short term lending such as interest rates on overdrafts. And then it changes the interest rates charge for the other loans too. Accordingly it is clear that the loan rates are normally changed in response to policy rate changes although there can be many other factors that affect the pricing of loan rates. In addition, the rates offered to savers by the banks can be changed in order to maintain the margin between deposit and loan rates. However, this margin can vary over time, and also vary additionally from bank to bank due to many reasons such as competitive conditions in the markets and the size of the bank. Accordingly, it is clear that the deposit rates of the banks do not normally change in response to policy changes alone (Cevik S and Teksoz K, 2012).

Though the bank retail interest rates are considered as a very effective channel of transferring policy changes to the market interest rates, this pass-through might occur at different degrees and at different speeds for positive and negative monetary policy action. Therefore, the policy makers always have to be well aware about the speed and degree of interest rate pass-through and possible asymmetries in the process of transferring policy rate changes to bank interest rates for effective decision making. Identifying these asymmetries is also essential to have a stable financial sector in the economy as discussed above. Therefore, many studies have been conducted on 'degree' and 'speed' of pass-through and asymmetric behaviour of bank interest rates to changes in monetary policy rates. Moreover, asymmetric response of banking retail rates to money market rates also has major consequences for profit margins, interest rate risks and the overall performance of the banking industry. 


\subsection{Reasons for Incomplete Interest Rate Pass-Through}

It is generally accepted that the success of monetary policy in achieving its goals will depend to a large extent on the 'stickiness' of market retail interest rates. The stickiness of market retail rates is often regarded as an obstacle to the smooth transmission of monetary policy impulses. Therefore, the pass-through of money market rates to bank retail rates can be incomplete in practice [Hannan and Berger (1991) and Cottarelli and Kourelis (1994)]. The incompleteness may vary across economies and across different retail rates of the economy. Therefore, a systematic measure of the degree of response of market interest rates to changes in monetary policy stance is essential.

The bank retail rates are rigid in the short-run to changes in money market rates due to many reasons. One of the main reasons for the short-term stickiness is that the adjustment or menu costs. Adjustment or menu cost refers to the cost involve in changing the prices which the banks have already advertised. Such costs impact banks to react sluggishly towards changes in the money market rates.

Also, 'maturity mismatches of banks' loan and deposit portfolio impacts how they adjust their lending rates. Thus, the banks will have less pressure when more long term loans are covered by long term deposits, if their liabilities have less sensitivity towards market rates. The same explanation was given by Kobayashi. The short-term maturities are affected by the current change in monetary policy rates. However, the longer maturities are influenced by both current and expected future short-term rates (Kobayashi T, 2008). Market expectations of the future path of interest rates play a major role in this regard. For example, a rise in the official interest rate could generate an expectation of lower future interest rates. In this case the long-term interest rates might fall in response to a rise in the official interest rate. This is called the asymmetric impact of monetary policy changes on bank retail rates. On the other hand, if banks issue long-term loans mostly based on the short-term borrowings then this maturity mismatch tends to change the retail rate on long-term loans frequently following the changes of money market interest rates.

Bank retail interest rates are sticky due to the shifting/switching cost that can be associated when consumers or corporate attempt to shift the banking institution. For example, suppose 
that lending rates are higher in bank $\mathrm{A}$ than bank $\mathrm{B}$ and that the borrower wants to settle the advance he obtained from bank $A$ to shift to bank B. In this case there can be some settlement cost that reduces the motivation of borrower to shift to bank B. In such a scenario there is not much incentive to reduce the prevailing bank rates on the issued loans following a reduction in policy rate.

The market structure and the competitiveness of the banking sector also play a major role in the change in bank retail rates. If a bank has a potential market power, then it increases the retail rate on loans frequently even with a slight increase in the money market rate or policy rate (Bondt, 2002, Mojon, 2000). If the financial market is highly competitive, the banks cannot change the prices of their products at their discretion as customers may shift to another bank. Therefore, retail bank rates are mostly sticky in a competitive financial market. The degree of competition plays a more important role for the deposit rates pass through than for the lending rates pass through (Coricelly et al, 2006).

Size of the interest rate spread also plays a role in stickiness in bank retail rates. Interest rate spread is the difference between the interest rate charged by banks on loans to private sector customers and the interest rate paid by commercial banks for demand, time, or savings deposits. The bank spreads are determined by factors such as macroeconomic environment, the banking sector's market structure, bank-specific factors, and financial regulation (Brock and Rojas-Suarez, 2000). High spreads between deposit and borrowing rates can lead to inefficient financial sector intermediation as well as curtailing investments in the economy. It is supported by the studies that transmission in changes of policy rates is quicker in loan rates than in deposit rates.

For all these reasons, the interest rates pass-through process could be incomplete and could be disrupted.

\subsection{The Role of Banks in the Interest Rate Transmission Mechanism}

Commercial banks are traditionally the most important entities for the collection of savings and the financing of firms and households. Therefore, adjustments of retail lending and deposit rates by banks can significantly influence economic activity. In that sense, the bank 
retail rates play an influential role (Peek J and Rosengren E S, 2013). Banking activities are also important as the financial products of the banks are considered non-substitutable products. Banking products still play a major role in most economies as non-bank financial markets cannot play such a role in those economies. However, this can be different for a market like the US financial market, where other financial institutions also play a major role in providing financial services to the economy.

Banking institutions are special as they are among the few participants of OMO activities with the central bank. The central bank indeed deals with a small group of counterparties, among which are commercial banks, in its OMO activities. In the OMO, banks have the ability to borrow funds from the daily auction at a rate decided based on the bids of OMO participants. Banks also lend fund in the money market to other counterparties who have short-term liquidity requirements.

Banks play a very important role in the payment system due to their ability to create money through the creation of deposits. The main way banks create money is through their loans to customers. Whenever a bank creates a loan, it creates a deposit in the borrower's bank account.

Accordingly, it is clear that banks are very special in the financial market in many ways. With these important roles, banks act in a special way to pass the monetary policy impulses to the real side of the economy. Accordingly the bank retail rates are always considered as a very influential and effective way to transmit monetary policy changes to the whole economy.

\section{Literature Review of Empirical Studies on Interest Rate Pass- through}

\subsection{Introduction}

The transmission of monetary policy impulses to bank retail interest rates, the interest rate pass-through process, occurs over various channels such as market interest rates, asset prices, market expectations, credit, etc. The cost channel or the market interest rate plays a major role among those channels as it describes how monetary policy changes are transferred to retail bank rates directly through the cost of funds. Policy makers are always 
attentive to understand the monetary policy impulses on bank retail rates. Therefore, many studies have been conducted on the subject of the impact of policy rates to retail interest rates. These analyses have been done for various economies and using many types of methodologies and tools. They shed light on the completeness and speed of interest rate pass-through to bank retail rates as well as on the asymmetric impact of monetary policy on bank interest rates. During the course of this literature review, the main features of the significant studies on interest rate pass-through will be discussed in detail, while highlighting the determinants of the interest rates pass-through and the findings and the methodologies used in those studies.

\subsection{The Degree, Speed and Asymmetry of the Transmission of Monetary Impulses to Bank Retail Rates}

The speed of transmission of monetary impulses to retail interest rates can be slow and the degree of transmission can vary across financial institutions, retail rates and products maturities. Further, asymmetries in the transmission might occur in response to positive and negative monetary policy changes. The conclusions reached by empirical studies on each of these features are discussed below.

\subsubsection{Incompleteness}

Berstein and Fuentes (2003), Burgstaller (2003), De Bondt (2002) conducted studies on the hypothesis of bank lending rates sluggishness to changes in policy interest rates for the Chilean economy, Austria and Europe. They all reached the same conclusion for short-term stickiness of retail bank lending rates. The studies focused on the response of commercial banks' lending rate to a money market interest rate movement during this period. They were successful in proving the sluggishness of money market rates and the policy rate in those countries. Accordingly, the studies indicated several characteristics such as the size of the bank, structure of the financial market, type of customers, competitiveness of the banking sector, elasticity of the demand on banking services and information asymmetry in the economy and the loan risk level that makes stickiness of interest rate pass-through in the 
short-run. Also, a cross country study to assess retail rate stickiness was conducted for Asia by Tai, Sek and Har (2012). This study consists of two periods: before the Asian financial crisis and after the financial crisis. The study reveals that the transmission rate from money market interest rate into deposit and lending rates was slow and sluggish across economies before the crisis. It continued to prevail after the Asian financial crisis of 1997/1998 due to low effectiveness of monetary policy, imperfect financial markets and the lower degree of financial integration of relevant economies. In general, the study concludes that the passthrough of policy rates to retail banking rates is sticky and thereby the effectiveness of the monetary policy in achieving policy targets is very low among the Asian economies studied.

Some contradictory results have been found by several studies. Those studies revealed that the interest rate pass-through tends to be full in the short run. For example, Crespo Cuaresma et al. (2004) empirically proved that the interest rate transmission to corporate lending rates was almost complete in the short run in five Central and Eastern European countries. They found that the deposit rate pass-through tends to be sticky in both short and long run. Further, in contrast to common finding of short-term stickiness of interest rate pass-through, some empirical studies have found evidence of an incomplete pass-through of the policy rate even in the long run. The empirical work by Mojon (2000), Heinemann and Schuler (2002), Hofmann (2003), and Sander and Kleimeier (2004) reported that the longrun pass-through of interest rates on loans to firms is complete. However, the empirical work by Donnay (2001) and Toolsema, Turm (2001) proved that the loan rate pass-through is incomplete in the long run.

\subsubsection{Speed of Adjustment}

Speed of adjustment of bank retail rates to policy rates refers the circumstance as the policy interest rate increases (decreases), correspondingly how quickly the standard-variable rate rises (drop) and vice versa. If there exists a significant asymmetry in speed of interest rate adjustments for deposit rates and lending rates, then banks are profiting from the policy rate changes. This may lead to developing a bad impression in the light of publicly held beliefs regarding increasing bank profits. Liu, Liu, Margaritis and Tourani-Rad (2011) found that 
banks in Australia and New Zealand are very slow to pass on reductions in official interest rates and/or cost of funds to borrowers, as a result of which they are making profits at the expense of their customers.

\subsubsection{Asymmetric Behaviour}

The asymmetric nature of the interest rate pass-through process in size and speed is also an important aspect of the transmission mechanism. In terms of magnitude of the adjustment, it is observed that bank loan rates are 'rigid to tightening' of monetary policy while deposit rates are 'rigid to easing' of monetary policy. Explanations for such rigidities can be attributed to the customers' unfavourable reactions to unstable rates and the unwillingness of the banks to break collusive price arrangements [Hannan and Berger (1991) and Neumark and Sharpe (1992)]. In terms of speed of adjustment, retail rates depend on whether the perceived gap between the retail and the base rates is widening or narrowing [Sander and Kleimeier (2004)].

Gambacorta and Iannotti's (2007) intuition was that the interest rate adjustment may be asymmetric in size and speed. For example, in the case of a monetary tightening, if banks had some market power, they could increase their loan rate by a higher percentage more and faster than their deposit rate, and vice versa, in the case of an easy monetary policy. This behaviour implies asymmetric adjustment of bank rates both in magnitude and speed and in order to examine such asymmetry, the model allows for asymmetric behaviour. They observed that interest-rate adjustments, in response to positive and negative shocks, are asymmetric in the short-run, although not in the long-run for Italy during the period of 1985 to 2002. This is consistent with the idea that in the long-run, the equilibrium is unique and banks adjust their loans (deposit) prices at a faster rate during periods of monetary tightening (easing).

The market practice of adjusting lending rates to increases in monetary policy rates faster than adjusting lending rates to decreases in monetary policy rates is referred to in the literature as "Rockets and Feather Hypothesis" [Valadkhani and Anwer (2012)]. The "Rockets and Feather Hypothesis" was tested by Valadkhani and Anwer (2012), for the 
speed of adjustments of 'mortgage lending rates' to 'cash rates' in Australia in the period of 1989 to 2011. They found that rate rises are passed onto the consumer faster than rate cuts. Conversely, when actual mortgage rates are above the equilibrium path, lenders usually hesitate to lower their rates.

\subsection{Determinants of Interest Rate Pass-through}

Heterogeneity in Strength of Interest Rate Pass-through in Cross Countries: The strength of the interest rate pass-through varies across countries and markets. Cross country heterogeneity has been revealed by pioneering work on determinants of interest rate passthrough covering 31 developed and emerging economies, Cottarelli and Kourelis (1994), which found that a higher inflationary environment, capital mobility, and money market development (proxied by volatility of money market rates or by the size of the market for short-term securities) result in a stronger pass-through. Similar results for inflation and money market volatility were obtained for different groups of European countries by Mojon (2000), and Sander and Kleimeier (2004).

Competition in the Banking Sector: The literature appears unanimous about the positive role of competition in the banking system for the pass-through process. Different researchers have used different measures of competition: Cottarelli and Kourelis (1994) used concentration of banking sector and a measure of private ownership of banks, Mojon (2000) used an index capturing the degree of banking deregulation in Europe, and Sorensen and Werner (2006) used banking concentration and market power measured by return on equity (ROE), also for a group of European countries. But all came to the conclusion that competition tends to improve pass-through.

Other Factors: Apart from these commonly used variables, Sorensen and Werner report a negative relationship of pass-through elasticity with banks' excess liquidity, excess capital, rigidity of bank funding costs (share of deposits in total liabilities), and interest rate risk (measured by maturity mismatch). They also find that portfolio diversification (share of noninterest income in total income) and credit risk (loan provisioning) improve passthrough. Sander and Kleimeier (2004) find that the financial health of the banking sector, 
inversely proxied by nonperforming loans as a per cent of total loans, reduces interest rates stickiness. Mojon (2000) reports that high operating costs, measured as staff costs to gross income, impede pass-through.

In general, most of the studies have found that the strength of interest rate pass-through depends on a range of factors such as composition and the growth of GDP, inflation, interest rates, credit quality, overhead costs and competition among banks which facilitate the pass-through process; market volatility and excess liquidity in the banking system, on the other hand, impede it. Countries with fixed exchange rate arrangements tend to have weak pass-through [Gigineishvil N (2011)].

\subsection{Econometric Methodologies to Measure Interest Rate Pass-through}

Transmission of monetary policy changes to retail bank rates using money market rates occurs at different speeds and different degrees. Therefore, there should be a proper mechanism or a way to measure the degree and the speed of interest rates pass-through. As the matter is important, several advanced statistical and econometric tools have been developed by scholars to assess the degree and the speed at which bank retail rates adjust to changes in money market rates. Econometric models have become more popular in this regard during the past few decades. Such econometric tools and methodologies used by major studies are discussed in the following sections.

\subsubsection{The Simple Regression Analysis using OLS Estimators}

This is a very popular and simple approach to econometric modelling to formulate the simplest equation that is consistent with a certain economic theory. Under this method, the researchers first select the relevant variables. Then the coefficients are estimated using the regression analysis. The qualities of the estimated coefficients are then evaluated by performing certain tests such as significance of the coefficients using t-tests and f-tests, Pvalues and $\mathrm{R}$ squared as well as co-integration. Regression analyses are more common in estimation responses of bank retail rates to changes in money market interest rates. 


\subsubsection{The Vector Auto Regressive Models}

The vector auto regression (VAR) model is one of the most successful, flexible, and easy to use models for the analysis of multivariate time series. It is an extension of the univariate autoregressive model to dynamic multivariate time series. The VAR model has proven to be especially useful for describing the dynamic behaviour of economic and financial time series and forecasting. It often provides superior forecasts to those from univariate time series models. It can model many equations at the same time. The VAR methodology is also used when the variables are integrated at levels.

The VAR equations describe a system in which each variable is a function of its own lag, and the lag of the other variables in the system. For an example, if the system contains two variables $\mathrm{y}$ and $\mathrm{x}$, and maximum lag is of order one, we refer such VAR models as 2-VAR (1). If $\mathrm{y}$ and $\mathrm{x}$ are stationary, the system can be estimated using least squares applied to each equation. If $\mathrm{y}$ and $\mathrm{x}$ are not stationary in their levels, but stationary in differences (i.e., $\mathrm{I}(1)$ ), then we take the first differences and estimate the model using least squares. In the VAR model we can consider all the variables as endogenous variable.

Let $Y_{t}=\left(y_{1}, y_{2 t}, \ldots, y_{n t}\right)$ denote an $(n \times 1)$ vector of time series variables. The basic p-lag vector autoregressive (VAR (p)) model has the following form

$$
Y_{t}=c+\prod 1 Y_{t-1}+\prod 2 Y_{t-2}+\cdots \ldots \ldots \ldots+\prod p Y_{t-p}+\varepsilon_{t}, \quad t=1, \ldots \ldots, T
$$

Where $\Pi \mathrm{i}$ are $(\mathrm{n} \times \mathrm{n})$ coefficient matrices and $\varepsilon_{\mathrm{t}}$ is an $(\mathrm{n} \times 1)$ unobservable zero mean white noise vector process (serially uncorrelated or independent) with time invariant covariance matrix $\Sigma$. For example, a bivariate VAR (2) model equation by equation has the form

$$
\left(\begin{array}{l}
Y_{1 t} \\
Y_{2 t}
\end{array}\right)=\left(\begin{array}{l}
c_{1} \\
c_{2}
\end{array}\right)+\left(\begin{array}{l}
\pi_{11} \pi_{12} \\
\pi_{21} \pi_{21}
\end{array}\right)\left(\begin{array}{l}
Y_{1 t-1} \\
Y_{2 t-1}
\end{array}\right)+\left(\begin{array}{l}
\pi_{11} \pi_{12} \\
\pi_{21} \pi_{21}
\end{array}\right)\left(\begin{array}{l}
Y_{1 t-2} \\
Y_{2 t-2}
\end{array}\right)+\left(\begin{array}{l}
\varepsilon_{1 t} \\
\varepsilon_{2 t}
\end{array}\right)
$$

Where $\operatorname{cov}\left(\varepsilon_{1 \mathrm{t}}, \varepsilon_{2 \mathrm{~s}}\right)=\sigma 12$ for $\mathrm{t}=\mathrm{s} ; 0$ otherwise. Each equation has the same regressors lagged values of $y_{1 t}$ and $y_{2 t}$. Hence, the VAR (p) model is just a seemingly unrelated regression (SUR) model with lagged variables and deterministic terms as common regressors. 
The information criteria of Akaike Information Criteria and Schwarz Criteria and the log likelihood ratio are used to select the lag length in the VAR models.

De Bondt (2002) conducted a study using VAR model at levels, which is the data series stationary at levels to examine the retail bank interest rate pass-through process in the euro area during the period of January 1996 to May 2001. He observed the interest rate passthrough process according to the impulse responses using the VAR. The impulse responses explain how a temporary shock to the market interest rate is passed through to bank deposit and lending rates, respectively. He found that shocks in the market interest rates are not immediately reflected in retail bank interest rates. In other words, bank interest rates are sticky in the short term.

Although VAR models are popular in the empirical analysis of interest rate pass-through, there is some criticism on the grounds of that there is not much economic theory behind them [Stock and Watson (2001)]. This criticism was addressed by introducing a structural VAR (SVAR) method, which has the economic background that is widely used in empirical analysis of interest rate pass-through.

Sengupta (2013) conducted a study using SVAR to examine whether the interest rate passthrough process has changed due to the introduction of the Liquidity Adjustment Facility (LAF) in India in 2000. The LAF has been introduced to minimize volatility in the money market by ensuring the movement of short-term interest rates within a reasonable range. The study observed that the interest rate pass-through has been improved after the introduction of LAF in India.

\subsubsection{The Error Correction Mechanism}

Error Correction Models (ECMs) are a category of multiple time series models that directly estimate the speed at which a dependent variable returns to equilibrium after a change in an independent variable. The ECMs are useful for estimating both short-term and long-term effects of one time series on another. Thus, they often use a theoretically-driven approach to estimate time series models. The ECMs are useful models when dealing with integrated data series, but can also be used with stationary data series. The basic structure of an ECM is 


$$
\Delta \mathbf{Y}_{\mathrm{t}}=\alpha+\alpha_{0} \Delta \mathbf{X}_{\mathrm{t}-1-\beta_{1}} \mathrm{EC}_{\mathrm{t}-1}+\varepsilon_{\mathrm{t}}
$$

Where $\mathrm{EC}=\mathrm{Y}-\beta_{0} \mathrm{X}$ is the error correction component of the model and measures the speed at which prior deviations from equilibrium are corrected. The short term effect of $\mathrm{X}$ on $\mathrm{Y}$ is $\beta_{1}$ which is the speed at which $\mathrm{Y}$ returns to equilibrium after a deviation has occurred. The long term effect of X on Y (long run multiplier) is $\alpha_{0}$. The ECMs are used in economic analysis as there are a number of desirable properties such as estimates of short and long term effects together which provide an easy interpretation of short and long term effects. They provide applications to both integrated and stationary time series data, which can be estimated using OLS, where the model also has a theoretical relationship. Accordingly, using ECMs can be appropriate whenever the researcher uses time series data and is interested in both short and long term relationships between multiple time series.

ECM representations are widely used in empirical analysis of interest rate pass-through due to the advantages discussed above. The pass-through of money market interest rates to retail banking interest rates were modelled using ECM for Chile, the United States, Canada, Australia, New Zealand and Five European countries by Espinosa- Vega M A and Rebucci A, in 2003. Initially an ADL model was estimated which included a time trend to investigate the long run relationship among those rates.

$$
\operatorname{RetailR}_{t}=\alpha_{0}+\alpha_{1} t+\alpha_{2} M M R_{t}+\alpha_{3} \text { RetailR }_{t-1}+\alpha_{4} M M R_{t-1}
$$

The above indicates the relevant bank retail rate, MMR the money market rate while ' $\mathrm{t}$ ' represents the time trend. The trend was included to capture the disinflation process and other factors such as financial liberalization, structural liberalization that change slowly over time. And then they re-parameterized their ADL model by introducing an ECM term to the above ADL equation as follows.

$$
\Delta \operatorname{RetailR}_{t}=\alpha_{2} \Delta M M R_{t}+\beta_{3}\left(\operatorname{RetailR}_{t-1}-\alpha_{0}-\beta_{1}\right)+\beta_{2} M M R_{t}
$$

This ECM model allowed them to measure together the short-run speed of adjustment (error correction adjustment) of bank retail rates to its long-run equilibrium and the shortterm pass-through of monetary policy changes to bank retail rates. 
The short-run and long-run interest rates pass-through behaviour of Malaysia were analysed by Zulkhibri in 2012 using the ECM representation. The study compared the behaviour interest rate pass-through of various financial institutions that is banks and non-bank financial institutions. The results showed that both deposit and lending pass-throughs were incomplete and the speeds of adjustments would vary across financial institutions and retail rates.

\section{Data and Methodology}

\subsection{Introduction}

This section describes the variables, present statistics and methodology of the analysis to be used in the paper. Monthly data are used covering the period from January 2003 to December 2013. Data from 2003 are used because the CBSL introduced more active OMO in 2003. Under this more active OMO is conducted where market participants play a major role in setting the effective rate in the auction which directly impacts call money market rates. The source of the data is the CBSL. The main interest of this study is not in the implementation of monetary policy but its transmission under the new operations. Leaving out data prior to 2003 avoids confounding the effects of changes in the conduct of monetary policy upon the transmission.

\subsection{Description of Data}

\subsubsection{Definition of Data and Stylised Facts}

The variables used in this analysis are the policy interest rates (the repo and reverse repo rates of the central bank), the call money market rate, various types of retail lending rates and various types of retail deposit rates. A description of the data is given below. 


\section{CBSL Policy Rates and Inter-bank Call Money Market Rates}

The CBSL sets the repo and reverse repo rates. In a normal period of operation the interbank overnight call money market rate (IBCMR) is bound below by the overnight repo rate (REPO) and bound above by the overnight reverse repo rate (REVREPO). In periods of excess liquidity or illiquidity these bounds do not hold. The data on the REPO and REVREPO are monthly averages of the daily repo and reverse repo rates respectively. The data on the IBCMR is the monthly average of the daily weighted average of overnight interbank call money market rates. A plot of the REPO, REVREPO and the IBCMR of the period of study is given in the Figure 5.1. It is clear from this figure that IBCMR has been bounded by the policy rates most of the time. The exception is the period where the global financial crisis prevailed. The internal war experienced by Sri Lanka could be another reason for this unusual behaviour. Further, the CBSL conducted a relatively tight monetary policy during this period.

It has been shown in previous studies that there is generally a close relationship between the CBSL policy rates - the REPO and the REVREPO rates - and the IBCMR [Amarasekara (2005)]. Therefore, as mentioned before, in this analysis only secondary stage of passthrough is considered, i.e. from the IBCMR to the other bank retail rates.

Figure 5.1: Behaviour of CBSL Policy Rates and IBCMR

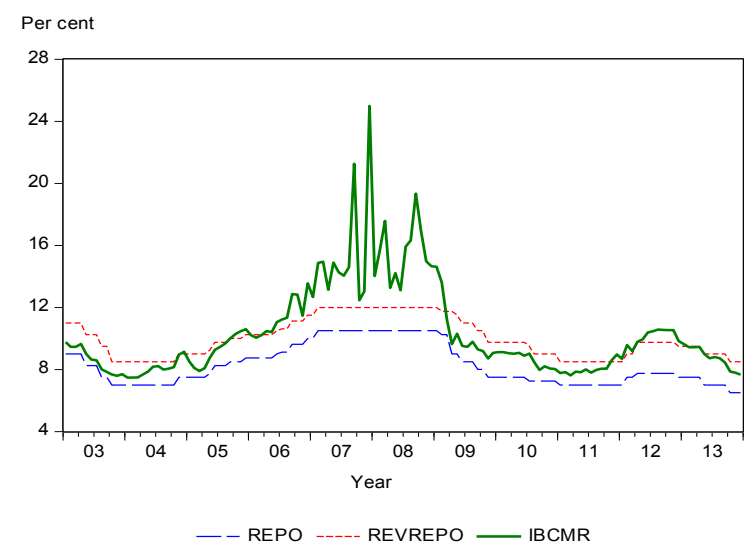




\section{Commercial Banks' Deposit Rates}

Various types of retail interest rates are considered to analyse the impact of the monetary policy on bank rates. The study contains four maturities of fixed deposits. They are the fixed deposit rates offered by the commercial banks on their three month fixed deposits (3MFD), six month fixed deposits (6MFD), twelve month fixed deposits (12MFD) and twenty four months fixed deposits (24MFD). Further, it was decided to analyse the commercial bank savings deposit rate (SD). The measurements of these variables used in the data are the middle rates of the commercial bank deposit rates as reported by the CBSL. In addition, the average weighted deposit rate (AWDR) of the commercial banks is also analysed. The AWDR is calculated by the CBSL monthly based on the weighted average of all outstanding interest bearing deposits of commercial banks and the corresponding interest rates on the deposit. The plots of these rates, with the IBCMR, over the sample period are shown in the plots in Figure 5.2.

Figure 5.2: Behaviour of the Bank Deposit Rates

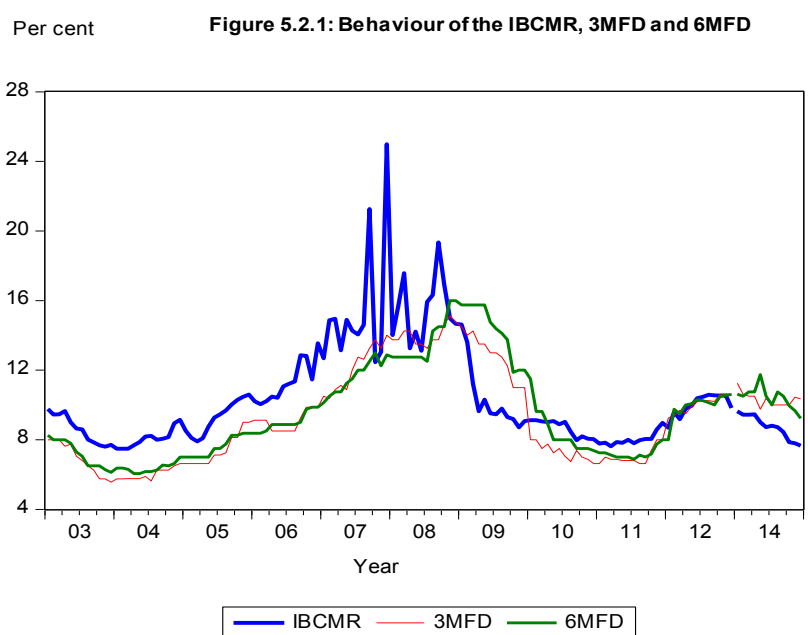




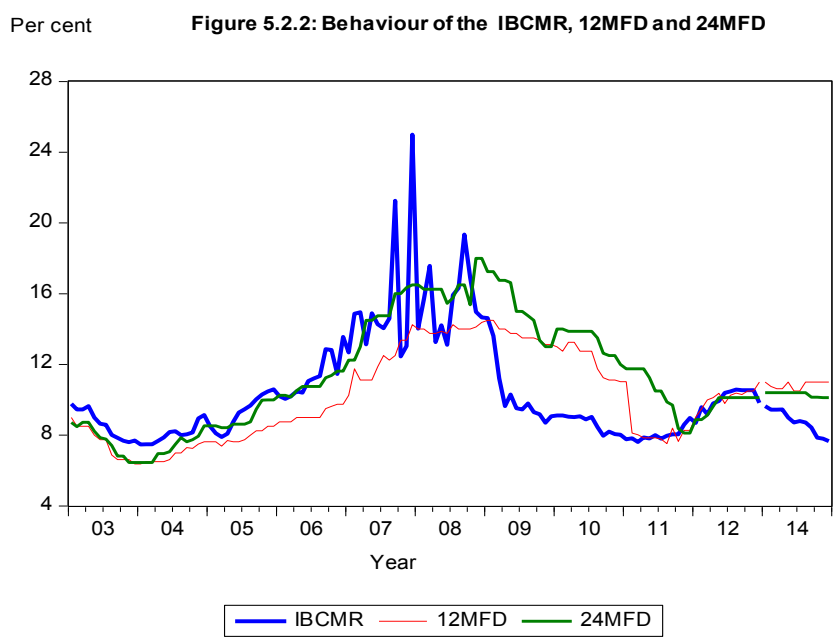

Per cent $\quad$ Figure 5.2.3: Behaviour of the IBCMR, SD and AWDR

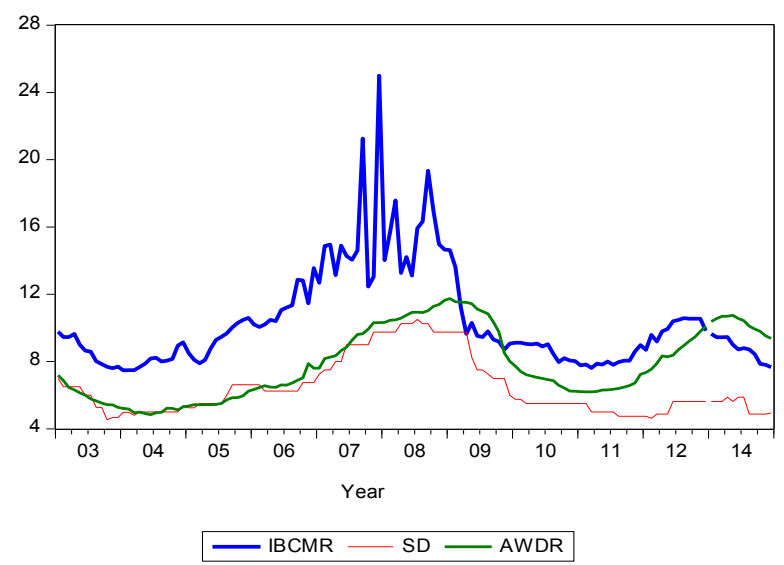

All of the deposit rates have followed the broad pattern of high interest rates which prevailed in the money market interest rates during the period of 2007-2009.

\section{Commercial Banks’ Lending Rates}

Various types of commercial bank lending rates are also considered in the analysis of the impact of the monetary policy. Two lending rates that are secured by collateral are considered. One of them is interest rates on loans secured by immovable properties 
(LSECIMPR). This is the middle rate of commercial banks' lending secured by property mortgages. It is rational to assume that this data series mainly comprises interest rates on long-term loans such as housing loans. The other series is interest rates on loans secured by other properties (LSECOTH). This is also the middle value data as reported by the CBSL.

It was decided, in addition, to consider interest rates on unsecured loans (LUNSEC) such as temporary overdraft facilities to analyse the monetary policy impact on those rates. The middle rate as reported by the CBSL is considered here as well.

The average weighted prime lending rate (AWPLR) is also considered. This rate is calculated by the CBSL weekly, based on commercial banks' lending to their prime customers during the week. The monthly figures are average values of weekly rates. This rate is useful to study the behaviour of prime lending rates.

The behaviour of these variables during the period under study is depicted in the plots in Figure 5.3.

\section{Figure 5.3: Behaviour of the Bank Lending Rates}

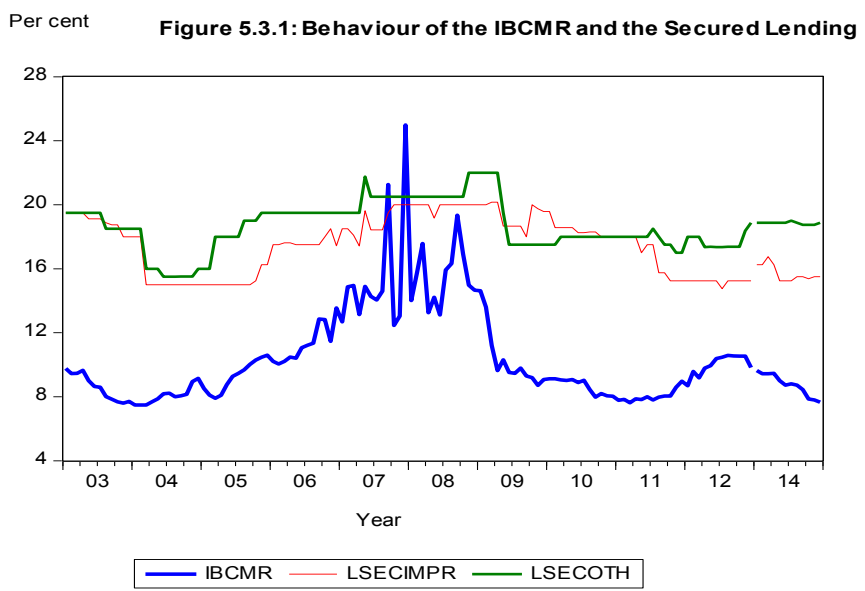




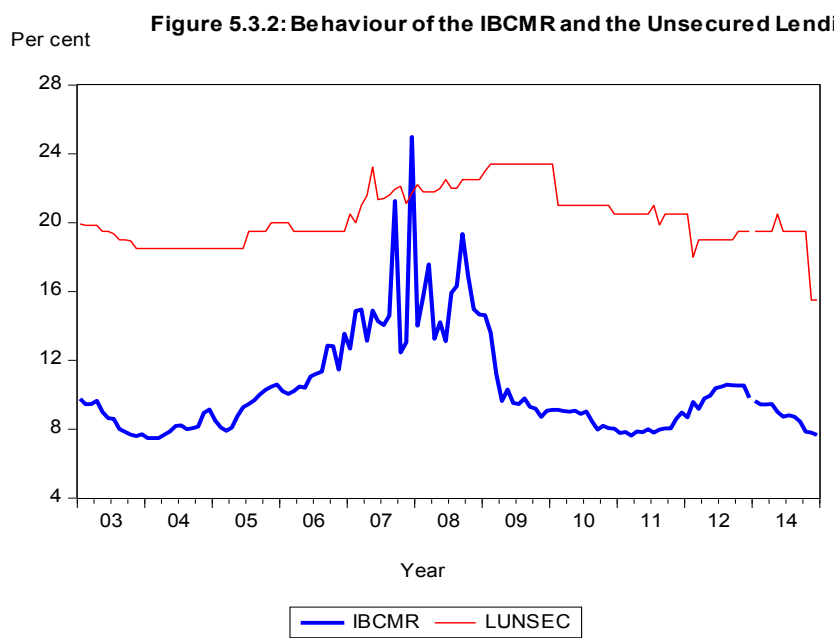

Figure 5.3.3: Behaviour of the IBCMR and Prime Lending Rate Per cent

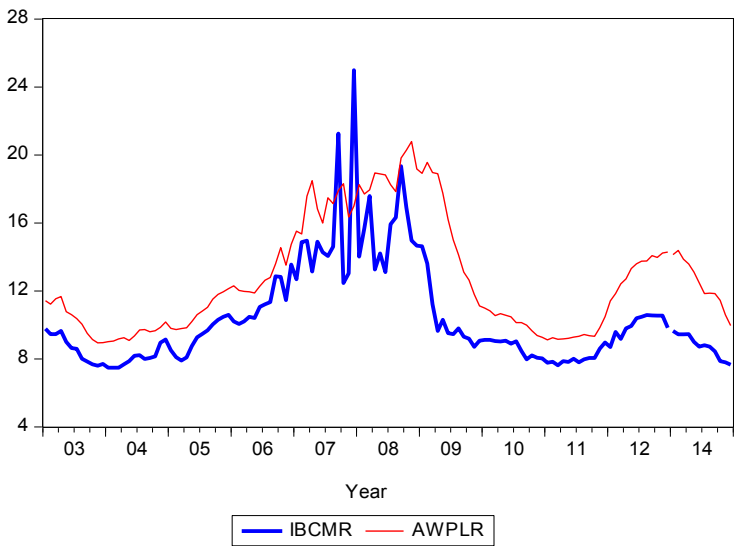

The main difference between the behaviour of deposit and lending rates (as shown in Figures 5.2 and 5.3) is that changes in lending rates (except in the case of prime lending rate) are not as frequent as deposit rates in response to monetary policy actions. This pattern suggests a greater rigidity of lending rates compared to deposit rates. However, the plots in Figure 5.2 and 5.3 show overall patterns in both of high interest rates during 2007-2009 periods. 


\subsubsection{Descriptive Statistics}

Descriptive statistics give a general overview of the data series aggregated over the sample period. The descriptive statistics of all monthly time series data are reported in Table 5.1.

Table 5.1: Descriptive Statistics of Monthly Interest Rates

\begin{tabular}{|c|c|c|c|c|c|}
\hline & Mean & Median & Maximum & Minimum & Std. Dev. \\
\hline \multicolumn{6}{|c|}{ CBSL Policy Rates } \\
\hline REPO & 8.29 & 7.75 & 10.50 & 6.50 & 1.32 \\
\hline REVREPO & 10.02 & 9.75 & 12.00 & 8.50 & 1.27 \\
\hline \multicolumn{6}{|c|}{ Money Market Rate } \\
\hline IBCMR & 10.36 & 9.45 & 24.99 & 7.48 & 2.99 \\
\hline \multicolumn{6}{|l|}{ Deposit Rates } \\
\hline 3MFD & 9.37 & 9.13 & 15.13 & 5.57 & 2.70 \\
\hline 6MFD & 9.62 & 8.95 & 16.00 & 6.06 & 2.70 \\
\hline 12MFD & 10.25 & 10.28 & 14.50 & 6.38 & 2.49 \\
\hline 24MFD & 11.36 & 10.40 & 18.00 & 6.46 & 3.11 \\
\hline $\mathrm{SD}$ & 6.45 & 5.63 & 10.50 & 4.55 & 1.71 \\
\hline AWDR & 7.85 & 7.20 & 11.74 & 4.84 & 2.12 \\
\hline \multicolumn{6}{|l|}{ Lending Rates } \\
\hline LSECIMPR & 17.42 & 18.00 & 20.17 & 14.75 & 1.85 \\
\hline LSECOTH & 18.67 & 18.63 & 22.00 & 15.50 & 1.51 \\
\hline LUNSEC & 20.29 & 19.90 & 23.40 & 15.50 & 1.63 \\
\hline AWPLR & 12.76 & 11.84 & 20.79 & 8.94 & 3.31 \\
\hline
\end{tabular}

The results in Table 5.1 show that, on average, the IBCMR has not remained between Repo and Reverse Repo rates, contrary to expectations. However, as depicted in Figure 5.1 the IBCMR remains in between policy rates of REPO and REVREPO except for the period of March 2006 to February 2009. The high volatility of the inter-bank market rate can be recognised as due to the market circumstances that prevailed during the period of financial turmoil around the world.

All deposit rates are on average below the IBCMR rate with the exception of the interest rate on $12 \mathrm{MFD}$ and 24MFD. The high rates for longer term maturity of fixed deposits are expected, since long-term deposits are compensated by a risk premium. 
On average, with the exception of the AWPLR, the lending rates are high relative to the deposit rates. The AWPLR is the lending rate for prime customers and therefore it is expected to be lower than the other interest rates. Further, the standard deviation of the AWPLR is higher compared to other lending rates. This shows that the AWPLR is more variable than other lending rates. Note that the standard deviations of the deposit rates are generally higher than those of the lending rates except AWPLR. This behaviour is evident in the plots discussed above and indicates that the lending rates are more rigid than the deposit rates.

\subsubsection{Correlation Structure}

Correlations between variables indicate the strength and direction of contemporaneous bivariate relationships among those variables. Table 5.2 depicts the correlations between all pairs of deposit rates including the IBCMR. All of the deposit rates have a positive correlation above 0.55 , with IBCMR. The interest rate on SD has the strongest correlation with IBCMR compared to others. The 3MFD is the next most strongly correlated with the IBMCR. On the other hand, the AWDR shows the lowest correlation with inter-bank call money market rate compared to the others.

Table 5.2: Correlation Matrix for Bank Deposit Rates

\begin{tabular}{llllllll}
\hline \hline & IBCMR & 3MFD & 6MFD & 12MFD & 24MFD & SD & AWDR \\
\hline IBCMR & 1 & 0.736452 & 0.646773 & 0.578995 & 0.667879 & 0.824835 & 0.555968 \\
3MFD & 0.736452 & 1 & 0.955114 & 0.828454 & 0.81879 & 0.844159 & 0.923688 \\
6MFD & 0.646773 & 0.955114 & 1 & 0.866302 & 0.848602 & 0.80665 & 0.927474 \\
12MFD & 0.578995 & 0.828454 & 0.866302 & 1 & 0.920117 & 0.713526 & 0.83513 \\
24MFD & 0.667879 & 0.81879 & 0.848602 & 0.920117 & 1 & 0.816937 & 0.746823 \\
SD & 0.824835 & 0.844159 & 0.80665 & 0.713526 & 0.816937 & 1 & 0.676189 \\
AWDR & 0.555968 & 0.923688 & 0.927474 & 0.83513 & 0.746823 & 0.676189 & 1 \\
\hline
\end{tabular}


Table 5.3 presents the correlation matrix for the bank lending rates and the IBCMR. The AWPRL shows the strongest correlation with inter-bank call money market rate. The LSECOTH also shows a strong correlation with IBCMR compared to the other two lending rates. The other lending rates do not show such strong correlations with IBCMR.

Table 5.3: Correlation Matrix for Bank Lending Rates

\begin{tabular}{llllll}
\hline \hline & IBCMR & LSECIMPR & LSECOTH & LUNSEC & AWPLR \\
\hline IBCMR & 1 & 0.504242 & 0.656183 & 0.466217 & 0.819293 \\
LSECIMPR & 0.504242 & 1 & 0.663615 & 0.715508 & 0.522853 \\
LSECOTH & 0.656183 & 0.663615 & 1 & 0.467393 & 0.737138 \\
LUNSEC & 0.466217 & 0.715508 & 0.467393 & 1 & 0.613653 \\
AWPLR & 0.819293 & 0.522853 & 0.737138 & 0.613653 & 1 \\
\hline
\end{tabular}

\subsection{Description of Methodology}

When discussing the deposit and lending rates described in Section 5.2, I will refer to these collectively as the bank retail rates. The IBCMR will be referred to as the money market interest rate.

\subsubsection{The Model}

Much of the literature on interest rate pass-through starts from the mark-up pricing model on the grounds of Rousseas (1985). The model can be written as;

$\mathrm{r}_{\mathrm{t}}^{\mathrm{b}}=\alpha_{0}+\beta \mathrm{r}_{\mathrm{t}^{-}}^{\mathrm{m}^{-}}+\varepsilon$

where $r^{b}$ is the retail lending rate charged by banks and the $r^{m}$ is the marginal cost approximated by the money market interest rate of the time t. $\alpha$ is the constant mark-up and $\beta$ is the pass-through parameter. $\varepsilon$ indicates the error term. As interest rates are usually found to be cointegrating non-stationary I (1) processes, Equation (1) can be estimated in the form of an error correction model capturing both the long-run equilibrium between retail rates and market rates as well as the short-run adjustment dynamics. 
As discussed in the theories on interest rate pass-through, there are two approaches that can explain the above relationship. The first is the "monetary policy approach" that addresses the linkage between bank lending rates and the policy rate (or short-term money market interest rate that is considered as a proxy to policy interest rate). The other is the "cost-offunds approach" that addresses the relationship between bank lending rates and money market interest rates. In this study, I follow the cost-of-funds approach.

The study focuses on three main issues. First, the study considers the completeness of the long-run pass-through. Second, it considers the short-run speed of adjustment and, finally, the asymmetries in the interest rate pass-through process.

The Long-run Relationship: The long-run relationship between bank retail rates and the money market rate can be modelled in the following way using a regression analysis among each pair of variables. This equation is the cointegrating relationship among those variables as it is considered that all the variables are cointegrated with money market rate.

$r_{t}^{b}=\alpha_{0}+\alpha_{1} I B C M R_{t}+\varepsilon_{t}$

where $\mathbf{r}^{\mathbf{b}}{ }_{t}$ represents the particular bank retail interest rates at time $t$ and $I B C M R_{t}$ represents the overnight money market rate at time t. As with the expression (1) for the deposit rates, the coefficient $\alpha_{0}$ is the constant mark-up and the coefficient $\alpha_{1}$ is the long-run interest rate pass-through parameter. These coefficients can be estimated using generalized method of moment (GMM) with the first lagged values of bank retail rate and first lagged value of money market rate as instruments. The GMM approach and choice of instruments are used to account for potential endogeneity, heteroskedasticity and auto correlation.

The Short-run Dynamics (ECM): The short-run dynamics of interest rate pass-through can be modelled in the following way using an error correction model [following Hefferman (1997), Scholnick (1996) and Winker (1999)]

$\Delta\left(\mathbf{r}^{\mathrm{b}}\right)=\mu+\varrho\left(\mathrm{r}^{\mathrm{b}} \mathrm{t}-1-\alpha_{0}-\alpha_{1} \operatorname{IBCMR}_{\mathrm{t}-1}\right)+\delta \Delta \operatorname{IBCMR}_{\mathrm{t}-1}+\varepsilon_{\mathrm{t}}$

Error correction adjustment is given by the coefficient $\varrho$ and the short-run pass-through is given by the coefficient $\delta$. 
The Asymmetric Model: To measure whether there is an asymmetry in the short-term dynamics in response to monetary easing and tightening, the following model is used [based on Scholnick (1996)];

$\Delta\left(\mathbf{r}^{\mathrm{b}} \mathrm{t}\right)=\delta_{0}+\delta_{1} \Delta \mathrm{IBCMR}_{\mathrm{t}-1}+\delta_{2} \varsigma_{\mathrm{t}-1}\left(\varepsilon_{\mathrm{t}-1}^{\prime}\right)+\delta_{3}\left(1-\varsigma_{\mathrm{t}-1}\right)\left(\varepsilon_{\mathrm{t}-1}^{\prime}\right)+v_{t}$

Where $\boldsymbol{\varepsilon}_{\mathbf{t}-1}$ is the estimated lagged $\varepsilon_{\mathbf{t}}$ in equation (2). $\varsigma$ is a dummy variable defined as follows; $\varsigma_{\mathrm{t}-1}=1$ if $\varepsilon_{\mathrm{t}-1}^{\prime}>0$ and 0 otherwise. Asymmetric mean lags (AML) are defined as follows;

$\mathrm{AML}^{+}=\left(1-\delta_{1}\right) / \delta_{2}$ and $\mathrm{AML}=\left(1-\delta_{1}\right) / \delta_{3}$

Asymmetry is examined using a Wald test with Chi-square (1) distribution for the null hypothesis $\delta_{2}=\delta_{3}$. A rejection of this hypothesis means that there is an asymmetric effect on pass-through depending on the direction of the policy change.

\subsubsection{Description of Econometric Tools used in the Analysis}

Unit Root Tests (ADF and KPSS tests): Augmented Dickey-Fuller (ADF) and the KPSS unit root tests are used to test for examine stationary property of variables.

\section{i) $\quad \mathrm{ADF}$ Test}

There are three versions of ADF tests based on the role of the constant term and the time trend included in the stochastic process.

ADF@ Level with Intercept and Trend: The following equation is estimated for each variable to test whether the series is stationary and to test whether there is a significant role for trend and the intercept to play in this analysis.

$$
\Delta y_{t}=\alpha+\gamma y_{t-1}+\sum_{s=1}^{m} a_{s} \Delta y_{t-s}+\lambda t+v_{t} \quad \text { Constant and trend }
$$

H0: $\gamma=0$, or Series has a unit root,

$$
\alpha=0 \text { or No constant and } \lambda=0 \text { or No trend }
$$


ADF@ Level with Intercept and No Trend: The following equation is estimated for each variable to test whether the series are stationary and to test whether there is a significant role for the intercept in the series.

$$
\Delta y_{t}=\alpha+\gamma y_{t-1}+\sum_{s=1}^{m} a_{s} \Delta y_{t-s}+v_{t} \quad \text { Constant only }
$$

H0: $\gamma=0$, or Series has a unit root,$\quad \alpha=0$ or No constant

ADF@ Level with No Intercept and No Trend: The following equation is estimated for each variable to test whether the series are stationary without including the trend and the intercept terms into the equation.

$$
\begin{gathered}
\Delta y_{t}=\gamma y_{t-1}+\sum_{s=1}^{m} a_{s} \Delta y_{t-s}+v_{t} \quad \text { No Constant or trend } \\
H 0: \gamma=0, \text { or Series has a unit root }
\end{gathered}
$$

\section{ii) The KPSS Test with Intercept and Trend}

The KPSS test is conducted to check whether the results given by the ADF test is valid in terms of another analysis.

Cointegration Tests (CRDW and Johansen tests): It is possible for there to be a linear combination of integrated variables that is stationary. Such variables are said to be cointegrated. Cointegration refers to a linear combination of non-stationary variables that is stationary. The residual based Durbin Watson and the Johansen procedure can be used to test the cointegration.

i) CRDW Test for Cointegration

The steps to test cointegration with CRDW can be given as follows;

- $\quad$ Consider the given variables $x_{t}, y_{t}$ and $z_{t}$ 
- $\quad$ Estimate $x_{t}=\alpha+\beta_{1} y_{t}+\beta_{2} z_{t}+e_{t}$ (by OLS)

- $\quad$ Test the residuals, $e_{t}$ for a unit root. If $e_{t}$ is I (0) then $x_{t} y_{t}$ and $z_{t}$ are cointegrated.

\section{ii) Johansen Test for Cointegration}

Johansen test for cointegration is based on VAR approach. It estimates the VEC model and test for the cointegration rank according to the following equation;

$$
\Delta x_{t}=\pi_{0}+\pi x_{t-1}+\pi_{1} \Delta x_{t-1}+\ldots+\pi_{p-1} \Delta x_{t-p+1}+e_{t}
$$

Where $e_{t} \sim \operatorname{NID}(0, \Sigma)$.

The number of cointegrating vectors is equal to the rank of $\pi$ denoted by $\mathrm{r}$.

The Johansen approach is to estimate the above equation for a given value of $r$. The rank of a matrix is equal to the number of its non-zero characteristic roots. This means we can test hypotheses concerning $r$ using the estimated characteristic roots of $\pi$.

There are two test statistics that can be used in Johansen test.

\section{(a) Trace Test Statistic}

We reject $\mathrm{H} 0: \mathrm{r}=\mathrm{r}^{*}$ in favour of $\mathrm{H} 1: \mathrm{r}>\mathrm{r}^{*}$ if the value of a trace test statistic is greater than critical values found in Johansen-Juselius tables.

\section{(b) Maximum Eigenvalue (Lambda Max) Test Statistic}

We reject $\mathrm{H} 0: \mathrm{r}=\mathrm{r}^{*}$ against $\mathrm{H} 1: \mathrm{r}=\mathrm{r}^{*}+1$ if the value of a maximum eigenvalue test statistic is greater than critical values in Johansen-Juselius tables.

Both tests have a non-standard chi-squared distribution. 


\section{Empirical Analysis and Results}

\subsection{Introduction}

The preceding section discussed the data used in the analysis and the methodology to be used in this section to conduct the analysis. The analysis begins with the unit root tests. If the series are integrated, I use two tests - CRDW test and Johansen test - to examine whether they have a long-run relationship (cointegration tests). Subsequently the short-run adjustment for long-run equilibrium would be analysed using the error correction model. Then the asymmetry of the monetary policy impact will tested. Finally the results will be summarised in the conclusion.

\subsection{Unit Root Tests}

The results of the ADF tests are given in the Table 6.1.

The test equations for the ADF test are as follows;

$$
\begin{gathered}
\Delta y_{t}=\alpha+\gamma y_{t-1}+\sum_{s=1}^{m} a_{s} \Delta y_{t-s}+\lambda t+v_{t} \quad \text { Constant and trend } \\
\Delta y_{t}=\alpha+\gamma y_{t-1}+\sum_{s=1}^{m} a_{s} \Delta y_{t-s}+v_{t} \quad \text { Constant only } \\
\Delta y_{t}=\gamma y_{t-1}+\sum_{s=1}^{m} a_{s} \Delta y_{t-s}+v_{t} \quad \text { No Constant or trend }
\end{gathered}
$$


Table 6.1: Summary Results of ADF Test for Unit Root

\begin{tabular}{|c|c|c|c|c|c|c|c|c|c|c|c|}
\hline \multirow{5}{*}{ Series } & \multirow{5}{*}{$\begin{array}{l}\text { Lag } \\
\text { Length }\end{array}$} & \multicolumn{10}{|c|}{ ADF Test } \\
\hline & & \multicolumn{5}{|c|}{ At Level } & \multicolumn{5}{|c|}{ At 1st Differences } \\
\hline & & \multicolumn{5}{|c|}{ Ho: $\gamma=0$, unit root and $\alpha=0$, No constant and $\lambda=0$, No Trend) } & \multicolumn{5}{|c|}{ Ho: $\gamma=0$ (Series has a UR) } \\
\hline & & \multicolumn{2}{|l|}{$\begin{array}{l}\text { Deterministic } \\
\text { Component }\end{array}$} & \multicolumn{3}{|c|}{ UR Test for Trend } & \multicolumn{5}{|c|}{ No Constant or Trend } \\
\hline & & $\begin{array}{l}\text { Constant or } \\
\text { Trend }\end{array}$ & P-Value & $\begin{array}{l}\text { ADF } \\
\text { Test } \\
\text { Stat }\end{array}$ & $\begin{array}{l}\text { Critical } \\
\text { Value } \\
\text { at } 5 \%\end{array}$ & Conclusion & P-Value & $\begin{array}{l}\text { ADF } \\
\text { Test } \\
\text { Stat }\end{array}$ & $\begin{array}{l}\text { Critical } \\
\text { Value at } \\
5 \% \\
\end{array}$ & $\begin{array}{l}\text { Conclusi } \\
\text { on }\end{array}$ & $\begin{array}{l}\text { Oder Of } \\
\text { Integration }\end{array}$ \\
\hline \multicolumn{12}{|c|}{ Money Market Rate } \\
\hline IBCMR & 2 & Not significant & 0.91 & -1.16 & -3.45 & Unit Root & 0.00 & -17.80 & -1.94 & No UR & I(1) \\
\hline \multicolumn{12}{|c|}{ Bank Deposit Rates } \\
\hline 3 Month-FD & 2 & Not significant & 0.90 & -1.24 & -3.45 & Unit Root & 0.00 & -12.95 & -1.94 & No UR & I(1) \\
\hline 6Month-FD & 2 & Not significant & 0.54 & -2.10 & -3.45 & Unit Root & 0.00 & -2.95 & -1.94 & No UR & I(1) \\
\hline 12 Month-FD & 2 & Not significant & 0.89 & -1.27 & -3.45 & Unit Root & 0.00 & -12.49 & -1.94 & No UR & I(1) \\
\hline 24 Month-FD & 2 & Not significant & 0.96 & -0.83 & -3.45 & Unit Root & 0.00 & -5.01 & -1.94 & No UR & $\mathrm{I}(1)$ \\
\hline Savings Deposit & 2 & Not significant & 0.95 & -0.93 & -3.45 & Unit Root & 0.00 & -10.52 & -1.94 & No UR & I(1) \\
\hline AWDR & 2 & Not significant & 0.29 & -2.59 & -3.45 & Unit Root & 0.01 & -2.72 & -1.94 & No UR & $\mathrm{I}(1)$ \\
\hline \multicolumn{12}{|c|}{ Bank Lending Rates } \\
\hline LSECIMPR & 2 & Not significant & 0.71 & -1.77 & -2.88 & Unit Root & 0.00 & -13.68 & -1.94 & No UR & I (1) \\
\hline LSECOTH & 2 & Not significant & 0.27 & -2.04 & -2.88 & Unit Root & 0.00 & -10.54 & -1.94 & No UR & I (1) \\
\hline LUNSEC & 2 & Not significant & 0.96 & -0.85 & -2.88 & Unit Root & 0.00 & -13.42 & -1.94 & No UR & I (1) \\
\hline AWPLR & 2 & Not significant & 0.27 & -2.62 & -2.88 & Unit Root & 0.03 & -2.19 & -1.94 & No UR & I(1) \\
\hline
\end{tabular}

It is evident that all the time series have one unit root and are therefore stationary in first differences. This means that all the variables are integrated at degree of one, I(1). These cesults are confirmed by the KPSS test (Figure 6.2) and compatible with past studies. 
Table 6.2: Summary results of KPSS Test for unit root

\begin{tabular}{|c|c|c|c|c|c|}
\hline \multirow[b]{4}{*}{ Series } & \multicolumn{5}{|c|}{ KPSS Test } \\
\hline & \multicolumn{2}{|c|}{ At Level with Constant and Trend } & \multicolumn{3}{|c|}{ 1st Difference with Constant and Trend } \\
\hline & \multicolumn{2}{|r|}{ HO: No UR } & \multicolumn{3}{|c|}{ HO: No UR } \\
\hline & $\begin{array}{l}\text { KPSS } \\
\text { Test } \\
\text { Stat }\end{array}$ & $\begin{array}{c}\text { Critical Value } \\
\text { @ } 5 \%\end{array}$ & $\begin{array}{l}\text { KPSS } \\
\text { Test } \\
\text { Stat }\end{array}$ & $\begin{array}{cc}\text { Critical } & \\
\text { Value } & \text { Conclusi } \\
@ 5 \% & \text { on }\end{array}$ & $\begin{array}{c}\text { Order } \\
\text { of } \\
\text { Integrat } \\
\text { ion }\end{array}$ \\
\hline \multicolumn{6}{|c|}{ Money Market Rate } \\
\hline IBCMR & 0.2292 & 0.1460 Unit Root & 0.0793 & 0.1460 No UR & $I(1)$ \\
\hline \multicolumn{6}{|c|}{ Bank Deposit Rates } \\
\hline 3 Month-FD & 0.2051 & 0.1460 Unit Root & 0.1055 & 0.1460 No UR & $\mathrm{I}(1)$ \\
\hline 6Month-FD & 0.2091 & 0.1460 Unit Root & 0.0887 & 0.1460 No UR & $\mathrm{I}(1)$ \\
\hline 12 Month-FD & 0.2538 & 0.1460 Unit Root & 0.1192 & 0.1460 No UR & $\mathrm{I}(1)$ \\
\hline 24 Month-FD & 0.3079 & 0.1460 Unit Root & 0.1169 & 0.1460 No UR & $\mathrm{I}(1)$ \\
\hline Savings Deposit & 0.2441 & 0.1460 Unit Root & 0.1251 & 0.1460 No UR & $\mathrm{I}(1)$ \\
\hline AWDR & 0.1568 & 0.1460 Unit Root & 0.1062 & 0.1460 No UR & $\mathrm{I}(1)$ \\
\hline \multicolumn{6}{|c|}{ Bank Lending Rates } \\
\hline LSECIMPR & 0.2218 & 0.1460 Unit Root & 0.1300 & 0.1460 No UR & I (1) \\
\hline LSECOTH & 0.1607 & 0.1460 Unit Root & 0.0663 & 0.1460 No UR & I (1) \\
\hline LUSEC & 0.2980 & 0.1460 Unit Root & 0.0806 & 0.1460 No UR & I (1) \\
\hline AWPLR & 0.2088 & 0.1460 Unit Root & 0.0937 & 0.1460 No UR & $\mathrm{I}(1)$ \\
\hline
\end{tabular}

Since all the variables are I (1), it is possible to see whether they are cointegrated. If the variables are not cointegrated, it is not possible to examine the long-run relationships as it could be a spurious relationship.

\subsection{Testing for Cointegration}

Since all money market and bank interest rates are considered as I (1), cointegration analyses were conducted based on both CRDW Test and Johansen procedure to examine whether there is a long-run relationship among the IBCMR and other variables.

Accordingly, the results of CRDW test are given in Table 6.3. 
Table 6.3: Summary of the CRDW Test Results

\begin{tabular}{lccl}
\hline \hline & DW & Critical Value at & Conclusion \\
Bank Lending Rate & Statistic & $\mathbf{5 \%}$ & Cointegrated \\
\hline 3FD c IBCMR & 0.5647 & 0.200 & Cointegrated \\
6FD c IBCMR & 0.3340 & 0.200 & Cointegrated \\
12FD c IBCMR & 0.2452 & 0.200 & Cointegrated \\
24FD c IBCMR & 0.3612 & 0.200 & Cointegrated \\
SD c IBCMR & 0.9764 & 0.200 & Cointegrated \\
AWDR c IBCMR & 0.2032 & 0.200 & Cointegrated \\
\hline Bank Deposit Rates & & & Cointegrated \\
\hline LSECIMPR c IBCMR & 0.2579 & 0.200 & Cointegrated \\
LSECOTH c IBCMR & 0.5212 & 0.200 & \\
LUNSEC c IBCMR & 0.2886 & 0.200 & 0.200 \\
AWPLR c IBCMR & 0.9821 & & \\
\hline
\end{tabular}

The CRDW test results suggest that all the pairs of variables (IBCMR with other variables) are cointegrated. The rank of the cointegration relation is one as there are only two variables in each test. The Johansen cointegration test with maximum eigenvalue and trace statistics are also conducted to examine these results (Table 6.4 and Table 6.5 respectively).

These tests confirm the above results of CRDW test except for two variables at 10 per cent significant level. Johansen Test-Maximum Eigen value does not conclude that there is a cointegration relationship between IBCMR with AWDR and LUNSEC. However, Johansen test-Trace Statistics concludes all the variables are cointegrated with IBCMR except LUNSEC. However, since CRDW concludes that all the variables are cointegrated with IBCMR, I consider that result for further analysis. 
Table 6.4: Summary of the Johansen Test Procedure with Maximum Eigen Value

\begin{tabular}{|c|c|c|c|c|c|}
\hline Variables Tested & $\begin{array}{l}\text { Hypothsis } \\
\text { (HO: r=r*; H1:r>r*) }\end{array}$ & Max-Eigenvalue & P-value & Decision & Conclusion \\
\hline \multicolumn{6}{|l|}{ Bank Deposit Rates } \\
\hline \multirow[t]{2}{*}{$3 F D \& I B C M R$} & $\mathrm{HO}: \mathrm{r}=0$ & 16.981 & 0.018 & Reject HO & Cointegrated \\
\hline & HO: $r<=1$ & & 0.074 & Do not Reject HO* & \\
\hline \multirow[t]{2}{*}{ 6FD \& IBCMR } & $\mathrm{HO}: \mathrm{r}=0$ & 22.940 & 0.002 & Reject HO & Cointegrated \\
\hline & HO: $r<=1$ & & 0.018 & Do not Reject HO** & \\
\hline \multirow[t]{2}{*}{ 12FD \& IBCMR } & $\mathrm{HO}: \mathrm{r}=0$ & 12.841 & 0.083 & Reject HO & Cointegrated \\
\hline & HO: $r<=1$ & & 0.023 & Do not Reject HO** & \\
\hline \multirow[t]{2}{*}{ 24FD \& IBCMR } & $\mathrm{HO}: \mathrm{r}=0$ & 24.355 & 0.001 & Reject $\mathrm{HO}$ & Cointegrated \\
\hline & $\mathrm{HO}: \mathrm{r}<=1$ & & 0.047 & Do not Reject HO** & \\
\hline \multirow[t]{2}{*}{ SD \& IBCMR } & $\mathrm{HO}: \mathrm{r}=0$ & 32.411 & 0.000 & Reject HO & Cointegrated \\
\hline & $\mathrm{HO}: \mathrm{r}<=1$ & & 0.086 & Do not Reject HO* & \\
\hline AWDR \& IBCMR & $\mathrm{HO}: \mathrm{r}=0$ & 12.222 & 0.103 & Do not Reject $\mathrm{HO}$ & Not Cointegrated \\
\hline \multicolumn{6}{|l|}{ Bank Lending Rates } \\
\hline \multirow[t]{2}{*}{ LSECIMPR \& IBCMR } & $\mathrm{HO}: \mathrm{r}=0$ & 15.496 & 0.032 & Reject HO & Cointegrated \\
\hline & $\mathrm{HO}: \mathrm{r}<=1$ & & 0.065 & Do not Reject HO* & \\
\hline \multirow[t]{2}{*}{ LSECOTH \& IBCMR } & $\mathrm{HO}: \mathrm{r}=0$ & 22.573 & 0.002 & Reject HO & Cointegrated \\
\hline & $\mathrm{HO}: \mathrm{r}<=1$ & & 0.172 & Do not Reject HO* & \\
\hline LUSEC \& IBCMR & $\mathrm{HO}: \mathrm{r}=0$ & 8.038 & 0.375 & Do not Reject & Not Cointegrated \\
\hline \multirow[t]{2}{*}{ AWPLR \& IBCMR } & $\mathrm{HO}: \mathrm{r}=0$ & 24.221 & 0.001 & Reject HO & Cointegrated \\
\hline & $\mathrm{HO}: \mathrm{r}<=1$ & & 0.091 & Do not Reject HO* & \\
\hline
\end{tabular}


Table 6.5: Summary of the Johansen Test Procedure with Trace Statistics

\begin{tabular}{|c|c|c|c|c|c|}
\hline Variables Tested & $\begin{array}{l}\text { Hypothsis } \\
\left(\mathrm{HO}: \mathrm{r}=\mathrm{r}^{*} ; \mathrm{H} 1: r=r^{*}+1\right)\end{array}$ & Trace Statistics & P-value & Decision & Conclusion \\
\hline \multicolumn{6}{|l|}{ Bank Deposit Rates } \\
\hline \multirow[t]{2}{*}{ 3FD \& IBCMR } & $\mathrm{HO}: \mathrm{r}=0$ & 20.167 & 0.009 & Reject HO & Cointegrated \\
\hline & $\mathrm{HO}: \mathrm{r}=1$ & & 0.074 & Do not Reject HO* & \\
\hline \multirow[t]{2}{*}{ 6FD \& IBCMR } & $\mathrm{HO}: \mathrm{r}=0$ & 28.506 & 0.000 & Reject HO & Cointegrated \\
\hline & $\mathrm{HO}: \mathrm{r}=1$ & & 0.018 & Do not Reject $\mathrm{H} 0^{* *}$ & \\
\hline \multirow[t]{2}{*}{ 12FD \& IBCMR } & $\mathrm{HO}: \mathrm{r}=0$ & 17.982 & 0.021 & Reject HO & Cointegrated \\
\hline & $\mathrm{HO}: \mathrm{r}=1$ & & 0.023 & Do not Reject $\mathrm{H} 0^{* *}$ & \\
\hline \multirow[t]{2}{*}{ 24FD \& IBCMR } & $\mathrm{HO}: \mathrm{r}=0$ & 28.287 & 0.000 & Reject $\mathrm{HO}$ & Cointegrated \\
\hline & $\mathrm{HO}: \mathrm{r}=1$ & & 0.047 & Do not Reject $\mathrm{HO}^{* *}$ & \\
\hline \multirow[t]{2}{*}{ SD \& IBCMR } & $\mathrm{HO}: \mathrm{r}=0$ & 35.355 & 0.000 & Reject HO & Cointegrated \\
\hline & $\mathrm{HO}: \mathrm{r}=1$ & & 0.086 & Do not Reject Ho* & \\
\hline \multirow[t]{2}{*}{ AWDR \& IBCMR } & $\mathrm{HO}: \mathrm{r}=0$ & 17.037 & 0.029 & Reject HO & Cointegrated \\
\hline & $\mathrm{HO}: \mathrm{r}=1$ & & 0.028 & Do not Reject $\mathrm{HO}^{* *}$ & \\
\hline \multicolumn{6}{|l|}{ Bank Lending Rates } \\
\hline \multirow[t]{2}{*}{ LSECIMPR \& IBCMR } & $\mathrm{HO}: \mathrm{r}=0$ & 18.903 & 0.015 & Reject $\mathrm{HO}$ & Cointegrated \\
\hline & $\mathrm{HO}: \mathrm{r}=1$ & & 0.065 & Do not Reject HO* & \\
\hline \multirow[t]{2}{*}{ LSECOTH \& IBCMR } & $\mathrm{HO}: \mathrm{r}=0$ & 24.437 & 0.002 & Reject $\mathrm{HO}$ & Cointegrated \\
\hline & $\mathrm{HO}: \mathrm{r}=1$ & & 0.172 & Do not Reject HO* & \\
\hline LUSEC \& IBCMR & $\mathrm{HO}: \mathrm{r}=0$ & 12.067 & 0.154 & Do not Reject HO & Not Cointegrated \\
\hline \multirow[t]{2}{*}{ AWPLR \& IBCMR } & $\mathrm{HO}: \mathrm{r}=0$ & 27.074 & 0.001 & Reject $\mathrm{HO}$ & Cointegrated \\
\hline & $\mathrm{HO}: \mathrm{r}=1$ & & 0.091 & Do not Reject HO* & \\
\hline
\end{tabular}

* Cointegrated at 5 p.c. level

** Cointegrated at 1 p.c. level

Although there are some exceptions, the above cointegration tests suggest it is reasonable to conclude that there is a long-run relationship among inter-bank call money rates and interest rate on commercial bank deposit and lending rates.

\subsection{Long-run Relationship among Inter-bank Call Money Market Rates and other}

\section{Rates}

The long-run relationship is examined using a regression analysis among each pair of variables, as I consider that all the pairs of variables are cointegrated. In this analysis, I use generalized method of moments (GMM) to account for potential endogeneity, heteroskedasticity, and autocorrelation. Table 6.6 shows the results of the regressions. 
Table 6.6: Long-run Relationship among Variables

\begin{tabular}{|c|c|c|c|}
\hline $\begin{array}{ll}\text { Bank } & \text { Interest } \\
\text { Rates } & \\
\end{array}$ & Mark up $(\alpha 0)$ & Pass-through $(\alpha 1)$ & Average \\
\hline \multicolumn{4}{|l|}{ Deposit Rates } \\
\hline $3 \mathrm{MFD}$ & 0.67 & 0.92 & \multirow{6}{*}{0.86 (Avg. Of FDs) } \\
\hline 6MFD & 0.94 & 0.78 & \\
\hline $12 \mathrm{MFD}$ & 1.80 & 0.75 & \\
\hline 24MFD & 0.21 & 0.99 & \\
\hline SD & 0.10 & 0.06 & \\
\hline AWDR & 1.04 & 0.06 & \\
\hline \multicolumn{4}{|l|}{ Lending Rates } \\
\hline LSECIMPR & 12.03 & 0.50 & \multirow{4}{*}{0.42} \\
\hline LSECOTH & 14.99 & 0.36 & \\
\hline LUNSEC & 15.84 & 0.39 & \\
\hline AWPLR & 0.22 & 1.18 & \\
\hline
\end{tabular}

Where the coefficients of $\alpha 0$ and $\alpha 1$ are given by the following long-run relationship:

$$
r_{t}^{b}=\alpha_{0}+\alpha_{1} I B C M R_{t}+\varepsilon_{t}
$$

and are estimated by GMM.

Long-run pass-through is equal to one if the pass through to demand for deposits or loans is one for one. According to Table 6.6, average pass through for fixed deposit rates is as high as 0.86. However, the pass-through is almost nil (0.06) for savings rates and AWDR. This is expected as the savings rate is almost a fixed rate in Sri Lanka which does not change frequently. The AWDR is the weighted average rate of all outstanding interest bearing deposits of commercial banks and the corresponding interest rates on the deposit. Therefore, it cannot reflect a clear picture of deposit rates.

Conversely, bottom panel of Table 6.6 shows that pass-through to the loan rates is much lower compared to the deposit rates. On average, the pass-through rate to loan rates is 0.42 , which is almost one half of the deposit rate. In this case also, AWPLR is different, the passthrough is more than 100 per cent. This shows that prime lending rate is mostly affected by the changes of money market rates in Sri Lanka. 
According to Table 6.6 the pass-through is below one for almost all interest rates showing that markets are imperfect in the sense information asymmetries. Further, information switching costs may also be a factor for low pass-through. However, the banks have better information of their prime lenders and the pass-through of AWPLR is greater than 1 .

\subsection{Short-Run Dynamics}

Table 6.7: Bi-Variate Error Correction Model- Testing for Short-run Dynamics

\begin{tabular}{lccc}
\hline \hline \multicolumn{1}{c}{ Variables } & $\begin{array}{c}\text { Short-term Pass- } \\
\text { through }(\boldsymbol{\delta})\end{array}$ & $\begin{array}{c}\text { Error Correction } \\
\text { Adjustment }(\varrho)\end{array}$ & Average \\
\hline Deposit Rates & & & \\
\hline 3FD & -0.140868 & -0.124876 & \\
6FD & -0.131177 & -0.106086 & \\
12FD & -0.143148 & -0.065836 & \\
24FD & -0.035269 & -0.092424 & -0.10394 \\
SD & 0.012663 & -0.201772 & \\
AWDR & 0.390581 & -0.032646 & \\
\hline Lending Rates & & & \\
\hline LSECIMPR & -0.203323 & -0.108224 & -0.14574 \\
LSECOTH & 0.122985 & -0.211577 & \\
LUNSEC & -0.153851 & -0.079621 & \\
AWPLR & 0.068714 & -0.183556 & \\
\hline
\end{tabular}

Where $\delta$ and $\varrho$ are given by following error correction model:

$\Delta($ Bank retail rate $)=\mu+\varrho\left(\right.$ Bank retail rate t $-1-\alpha_{0}-\alpha_{1}$ call money market rate t -1$)$

$+\delta \Delta$ call money market rate $\mathrm{t}_{\mathrm{t}-1}+\varepsilon_{\mathrm{t}}$

All the estimates of the error correction adjustment are negative, which means that the retail rates exhibit mean reversion to the long-run equilibrium. On average, short-run adjustment speed of deposit rates is less compared with the lending rates. Further, the short-run adjustment speed is higher for shorter maturities. 


\subsection{Asymmetry in Pass-through}

The results of the empirically evaluated asymmetric model are given in Table 6.8.

Table 6.8: Asymmetric Model of Short-Run Dynamics

\begin{tabular}{lcccccc}
\hline Bank Interest Rates & $\boldsymbol{\delta 1}$ & $\boldsymbol{\delta 2}$ & $\boldsymbol{\delta}$ & AML+ & AML- & Wald Test (p-value) \\
\hline Deposit Rates & & & & & & \\
\hline 3MFD & 0.05 & -0.18 & -0.15 & -5.30 & -6.21 & 0.90 \\
6MFD & 0.03 & -0.15 & -0.10 & -6.47 & -9.83 & 0.78 \\
12MFD & 0.01 & -0.11 & -0.13 & -8.83 & -7.58 & 0.59 \\
24MFD & 0.00 & -0.32 & 0.09 & -3.12 & 11.57 & 0.05 \\
SD & 0.00 & -0.24 & -0.08 & -4.24 & -13.18 & 0.45 \\
AWDR & 0.00 & 0.46 & 0.13 & 2.19 & 7.56 & 0.18 \\
\hline Lending Rtaes & & & & & & \\
\hline LSECIMPR & 0.02 & -0.35 & -0.28 & -2.85 & -3.46 & 0.75 \\
LSECOTH & -0.01 & -0.13 & -0.06 & -7.59 & -18.43 & 0.69 \\
LUNSEC & 0.06 & -0.15 & -0.26 & -6.47 & -3.57 & 0.57 \\
AWPLR & 0.13 & -0.12 & 0.03 & -7.02 & 27.71 & 0.46 \\
\hline
\end{tabular}

Note: The model is given by the following equation:

$\Delta\left(\mathrm{r}_{\mathrm{t}}^{\mathrm{b}}\right)=\delta_{0}+\delta_{1} \Delta \mathrm{IBCMR}_{\mathrm{t}-1}+\delta_{2} \varsigma\left(\varepsilon_{\mathrm{t}-1}^{\prime}\right)+\delta_{2}(1-\varsigma)\left(\varepsilon_{\mathrm{t}-1}^{\prime}\right)+v_{t} ; \mathrm{AML}^{+}=\left(1-\delta_{1}\right) / \delta_{2} ; \mathrm{AML}=\left(1-\delta_{1}\right) / \delta_{3}$.

The Wald test confirms that there is no asymmetric effect of monetary policy tightening or easing on interest pass-through for all the interest rates apart from twenty four month fixed deposit rate.

\section{Conclusion}

An efficient transmission of monetary policy impulses to the retail interest rates of the economy is undeniably important to achieve the ultimate goals of monetary policy. Sri Lanka is mainly a bank funded economy. Therefore, bank retail rates on lending and deposits have the ability to influence major economic activities such as investment and consumption. While most of the assets of the banking sector are loans, the liabilities of banks are mainly deposits. Therefore, interest rate pass-through from money market rates to lending and deposit rates of commercial banks are essential to understand the MTM of the country. This study attempts to understand the essential component of MTM in Sri Lanka. In this regard, 
Error Correction Mechanism is used in the current study as the main technique to analyse the interest rate pass through mechanism empirically. The data is during the 10 years period from 2003 to 2013.

The key conclusion is that, in general, there is no one for one interest rate pass-through to the long-run commercial bank rates from the money market rate. Nevertheless, there is a sizable pass-through in the long-run to fixed deposit rates. In contrast, the long-run passthrough is not satisfactory with regard to retail loan interest rates. All the variables; the considered deposit and lending rates showed a significant long-run relationship with interbank call money market rates.

In the short-run, bank retail rates that deviated from the equilibrium were adjusted to their equilibrium levels in the long-run. Also it was found that, on average, short-run adjustment speed of deposit rates is less compared with the lending rates. Further, the short-run adjustment speed is higher for shorter maturities.

It was also found that there is no asymmetric effect of monetary policy tightening or easing on interest pass-through for all the interest rates apart from twenty four month fixed deposit rate in Sri Lanka.

\subsection{Policy Recommendations}

According to the current analysis, although long-run interest pass-through is satisfactory with deposit rates, it is not the case for loan rates. However, loan rates are the most influential to the aggregate demand. Therefore, to conduct the monetary policy successfully, the impact of monetary policy impulses should be satisfactory with regard to loan rates. Therefore, the CBSL should consider ways and means of affecting loan interest rates effectively in the long run. One suggestion to achieve this task is to consider regulatory measures to impose maximum and minimum loan rates based on the official policy rate. However, this recommendation is subject to further studies with more compatible data as this study was based on the middle rates of bank deposits and loans. 


\subsection{Limitations of the Study}

This analysis was conducted using monthly data from 2003. This is due to the introduction of active OMO process in Sri Lanka in 2003. However, it would have been more satisfactory to conduct a comparison of interest rate pass-through before and after the introduction of active OMO process. It was impossible to conduct such a comparison due to the unavailability of monthly data before 2003 .

Further, most of the retail interest rates on loans and deposits were middle rates as there were no average rates found for them. If monthly average rates were available it would have given a much better idea of the retail rate behaviour of the commercial banking sector.

\subsection{Directions for Further Research}

This study opened up several areas for further research. Firstly, the study did not pay special attention to the determinants of interest rate pass-through in Sri Lanka. For example, it is found in the literature that the level of non-performing loans is an influential factor in the determination of interest rate pass-through to bank retail rates. The annual periodical of CBSL, Financial System Stability Review -2013 states that "Banks in Sri Lanka are facing relatively higher credit risk as indicated by the rising non-performing loans (NPLs)". Studying the effect of nonperforming loans on the pass-through process is therefore relevant. It is also worth conducting a study to identify the specific factors that determine the interest rate pass through in the Sri Lankan economy as well as factors that can limit the impact of monetary policy on bank retail rates.

Further, the banking sector is highly concentrated in Sri Lanka as six major banks have a systematically important role in the Sri Lankan financial market. This could have an impact on the interest rate pass-through in Sri Lanka. Therefore, it may be useful to study the determinants of interest rates pass-through in the Sri Lankan context. Also, the Sri Lankan commercial banking sector consists of states banks as well as private banks. A study can be conducted to measure the response of retail bank interest rates to changes in monetary policy rates in these two sectors separately. 
Further, this study did not consider the behaviour of retail interest rates of LSBs in Sri Lanka. This study only considered the impact on interest rates in LCBs. However, the total banking sector includes both the LCBs and the LSBs. More importantly, the LSBs play an increasingly important role in the Sri Lankan banking sector. Therefore, considering retail rates of LSBs would give a better understanding of the interest rate pass-through process. 


\section{References}

Amarasekara, C 2005, "Interest Rate Pass-through in Sri Lanka”, Staff Studies, Vol. 35, Central Bank of Sri Lanka.

2008, "The Impact of Monetary Policy on Economic Growth and Inflation in Sri Lanka”, Staff Studies, Vol. 38, Central Bank of Sri Lanka.

Aziakpono, MJ \& Wilson, MK 2010, “Interest Rate Pass-Through and Monetary Policy Regimes in South Africa”, Paper for presentation at the CSAE Conference, 21-23 March 2010, Oxford University, UK.

Berstein, J S \& Fuentes S, R 2003, “From Policy Rates to Bank Lending Rates: The Chilean Banking Industry.”, Economia Chilena, vol. 6, no. 1, pp. 49-67.

Brock, P L \& L Rojas-Suarez 2000, "Understanding the Behavior of Bank Spreads in Latin America," Journal of Development Economics, Vol. 63, pp. 113-34.

Burgstaller, J 2003, "Interest Rate Transmission to Commercial Credit Rates in Austria”, Economics Working Papers, Johannes Kepler University, Linz, Austria.

CBSL Annual Reports, 2000, 2002, 2011, 2013 and 2014, Central Bank of Sri lanka.

CBSL 2014, Central Bank of Sri Lanka Web Site, <Available Online: www.cbsl.gov.lk: [Date Accessed 10-01-2013].

Cevik, S \& Teksoz, K 2012, "Lost in Transmission? The Effectiveness of Monetary Transmission Channels in the GCC Countries”, IMF Working Paper/12/191.

Coricelli, F, Egert, B, \& MacDonald, R 2006, "Monetary Transmission Mechanism in Central and Eastern Europe: Surveying the Empirical Evidence”, In Finance and Consumption Conference, European University Institute.

Cottarelli, C \& Kourelis, A 1994, "Financial Structure, Bank Lending Rates, and the Transmission Mechanism of Monetary Policy”, IMF Staff Paper 41. 
Crespo-Cuaresma, J, Egert, B \& Reininger T 2006, "Interest Rate Pass Through in Central and Eastern Europe: Reborn from Ashes Merely to Pass Away", Oesterreichische Nationalbank, Focus on Europen Economic Integration No. 1.

De Bondt, G 2002, "Retail Bank Interest rate Pass-through: New evidence at the Euro Area Level”, European Central Bank, Working Paper Series, vol. Working Paper no.136.

De Bondt 2005, "Interest Rate Pass-through: Empirical Results for the Euro Area”, German Economic Review, vol. 6, no. 1, pp. 37-78.

Donnay, MHD 2001, "Bank Lending Rate Pass-Through and Differences in the Transmission of a Single EMU Monetary Policy", Discussion Paper No. 0117, Katholicke Universiteit Leuven Center for Economic Studies.

Espinosa-Vega, M \& Rebucci, A 2003, "Retail Bank Interest Rate Pass-through: is Chile Atypical", Central Bank of Chile Working Paper, no. 221.

Financial System Stability Review, 2013, The Central Bank of Sri Lanka.

Gambacorta, L \& Iannotti, S 2007, “Are there asymmetries in the response of bank interest rates to monetary shocks?”, Applied economics, vol. 39, no. 19, pp. 2503-17.

Gigineishvili, N. 2011, "Determinants of interest rate pass-through: Do macroeconomic conditions and financial market structure matter?", IMF Working Papers, International Monetary Fund, no. 11/176, pp.16.

Hannan, T \& Berger, A 1991, “The Rigidity of Prices: Evidence from the Banking Industry.” American Economic Review, 81:938-945.

Hefferman, S A 1997, "Modelling British Interest Rate Adjustment: An Error Correction Approach”, Economica, Volume 64, Issue 254, pages 211-231.

Heinemann, F \& Schuler, M 2002, "Integration Benefits on EU Retail Credit MarketsEvidence from Interest Rate Pass-Through.”, ZEW Discussion Paper no. 02-26.

Hofmann, B 2003, "EMU and the Transmission of Monetary Policy: Evidence from Business Lending Rates”, ZEI University of Bonn. 
Ireland, P N 2005, “The Monetary Transmission Mechanism”, Federal Reserve Bank of Boston, Working Paper, no. 06-1.

_ 2006, 'Inflation Targeting \& Central Bank Independence - New Directions for Sri Lanka's Monetary Policy?', Sri Lanka Economic Journal Vol.7 No. 1 \& 2. , pp. 65-90.

Kobayashi, T 2008, "Incomplete Interest Rate Pass-Through and Optimal Monetary Policy," International Journal of Central Banking, Vol 4(3), pp 77-118.

Liu, MH, Margaritis, D \& Tourani-Rad, A 2011, “Asymmetric Information and Price Competition in Small Business Lendin", Journal of Banking and Finance.

Mishkin, F 2013, “The economics of money, banking, and financial markets", Pearson, Harlow.

Mojon, B 2000, "Financial Structure and the Interest Rate Channel of ECB Monetary Policy”, ECB Working Paper no. 40.

Neumark, D \& Sharpe, S A 1992. "Market Structure and the Nature of Price Rigidity: Evidence from the Market for Consumer Deposits." Quarterly Journal of Economics, 107(2), pp. 657-680.

Peek, J \& Rosengren, E S 2013, “The Role of Banks in the Transmission of Monetary Policy", Public Policy Discussion Papers, Federal Reserve Bank of Boston, no. 135.

Sander, H \& Kleimeier, S 2004, "Convergence in Euro-Zone Retail Banking? What Interest Rate Pass-Through Tells Us about Monetary Policy Transmission, Competition and Integration”, Journal of International Money and Finance, vol. 23 (3): 461-92.

Scholnick, B 1996, 'Asymmetric adjustment of commercial bank interest rates: Evidence from Malaysia and Singapore', Journal of International Money and Finance 15, 485-496.

Sengupta, N 2013, "Interest Rate Pass-Through in India", Macroeconomic and Finanace in emerging Market Economies. 
Sorensen, C K \& Werner, T 2006, "Bank Interest Rate Pass-Thorough in the Euro Area: A Cross Country Comparison”, European Central Bank, Working Paper Series, no. 580.

Stiglitz, J \& Weiss, A 1981 “Credit Rationing in the Markets with Imperfect Information”, American Economic Review, no.71, pp. 393-410.

Stock, JH \& Watson, MW 2001, "Vector Autoregressions", The journal of economic perspectives, vol. 15, no. 4, pp. 101-15.

Tai, PN, Sek, SK \& Har, WM 2012, "nterest rate pass-through and monetary transmission in Asia”, International journal of economics and finance, vol. 4, no. 2, pp. 163-74.

Taylor, JB 1995, “The Monetary Transmission Mechanism: An Empirical Framework”, The journal of economic perspectives, vol. 9, no. 4, pp. 11-26.

Thenuwara, HN 1998, "The Scope for Inflation Targeting in Sri Lanka; a Focus on Transmission Mechanism”, Staff Studies, Vols 27-28, Central Bank of Sri Lanka.

Toolsema, LA, Turm, J \& J, DH 2001, “Convergence of Monetary Transmission in EMU: New Evidence”, CESifo Working Paper no. 465.

Valadkhani, A \& Anwer, S 2012, "Interest rate pass through and the asymmetric relationship between the cash rate and the mortgage rate", The Economic Record, University of Wollongon, vol. 88 (282), , pp. 341-50.

Winker, P 1999, "Sluggish Adjustment of Interest Rates and Credit Rationing: an Application of Unit Root Testing and Error Correction Modelling”, Applied Economics Journal, 31, pp. 267-277.

Zulkhibri, M 2012, "Policy rate pass-through and the adjustment of retail interest rates: Empirical evidence from Malaysian financial institutions”, Journal of Asian Economics, vol. 23, no. 4, pp. 409-22. 